\title{
37. MESOZOIC CARBONATE DEPOSITION ON THE OUTER CONTINENTAL MARGIN OFF MOROCCO ${ }^{1}$
}

\author{
Lubomir F. Jansa, Bedford Institute of Oceanography \\ Torsten H. Steiger, Institut für Geologie, Universität München \\ and \\ Martin Bradshaw, University of Aston ${ }^{2}$
}

\begin{abstract}
Deep sea drilling on the continental margin off Morocco provided valuable information on the development of Mesozoic carbonate platforms buried beneath outer continental slopes around the central North Atlantic. It also provided the first insight into Early Jurassic paleoceanography and the depositional history of the evolving Atlantic oceanic basin.

The block-faulted margin off Morocco, some blocks of which subsided below global sea level before the Early Jurassic, was transgressed by the sea during (?)Sinemurian time. Early pelagic carbonate deposits first became incorporated into limestone debris flows during the Sinemurian; they document slope instability. Debris-flow deposits continued to accumulate at the toe of the slope throughout the Jurassic, and are intercalcated with calcareous shales and finegrained limestones poor in indigenous fauna. The Middle Jurassic saw a marked decrease in deposition at the outer margin of the Mazagan Plateau, probably as a result of regression. The carbonate-ramp morphology of the slope which dominated the Early Jurassic began to change into an outbuilding and upbuilding carbonate platform during the Middle Jurassic; high-energy oolitic shoals and scattered coral-sponge bioherms were etablished during the Late Jurassic near the paleoshelf edge. Platform construction was terminated after the Berriasian and before the Aptian; during this period the outer edge of the platform was exposed to freshwater leaching and dolomitization that resulted in up to $30 \%$ porosity. At the toe of the slope, the reddish brown, Upper Jurassic nodular limestone lithofacies, which resembles the Cat Gap Formation and Ammonitico Rosso facies of the western North Atlantic Basin and the Mediterranean respectively, grades into light grey pelagic limestones typical of the Blake-Bahama Formation and Maiolica lithofacies.

The tectonic regime of the outer Mazagan Plateau is not well determined, but several stages of faulting during the Early Jurassic, Early Cretaceous, and Miocene are recognized as having modified the margin. The oxidized Upper and Middle Jurassic sediments deposited on the slope and basin floor off Morocco contrast with poorly oxygenated, medium gray to dark gray Lower Jurassic claystones and marls, which contain several organic-matter-rich shale beds. We suggest that low-oxygen conditions were the result of poor bottom water circulation, since the "Gibraltar-Rif" seaway to the Mediterranean Tethys was closed until the Pliensbachian, and bottom circulation did not improve until the opening of the central North Atlantic into the Pacific during the (?)early Middle Jurassic.
\end{abstract}

\section{INTRODUCTION}

The continental margin off Morocco has long been recognized as an ideal location to learn about the early history of rifting in the central North Atlantic, because its later history of sediment starvation enables access to the early deposits by deep sea drilling. Deep Sea Drilling Project Legs 41 and 50 were devoted to the study of the deep sea basin off Morocco, and Leg 79 was designed to study the adjacent continental margin. The four sites drilled during Leg 79 were located in a stepwise series down the Mazagan Escarpment in order to reconstruct the stratigraphy and depositional history of the deeper part of the continental margin. This approach proved to be successful, and an almost complete Jurassic section was encountered at one of the drilled sites. Since the Mazagan Plateau is capped by a carbonate platform, Leg 79 also provided a unique opportunity to study the development of the outer deep margin of a carbonate

\footnotetext{
${ }^{1}$ Hinz, K., Winterer, E. L., et al., Init. Reports. DSDP, 79: Washington; U.S. Govt. Printing Office).

2 Addresses: (Jansa) Geological Survey of Canada, Bedford Institute of Oceanography, Box 1006, Dartmouth, Nova Scotia B2Y 4A2 Canada; (Steiger) Institut für Geologie, UniverBox 1006, Dartmouth, Nova Scotia B2Y 4A2 Canada; (Steiger) Institut für Geologie, Univer-
sităt München, Federal Republic of Germany; (Bradshaw, present address) Shell International sităt München, Federal Republic of Germa
}

platform; such information is not obtainable from the Mesozoic carbonate platforms which rim the eastern North American margin because of their thick sedimentary cover (Jansa, 1981).

In this contribution we discuss the history and development of the outer carbonate platform off Morocco, the role of tectonism, and the depositional processes involved. We interpret the Leg 79 data in the broader context of passive margin evolution by incorporating information provided by previous DSDP legs offshore Morocco (Lancelot, Seibold, et al., 1979; Lancelot, Winterer, et al., 1980), dredging of the Mazagan Escarpment (Renz et al., 1975, Wissmann and von Rad, 1979) and the onshore geology (e.g., Ambroggi, 1963; Ager, 1974; Jansa and Wiedmann, 1982). The paucity of accurate and reliable paleontological age determinations for many of the Jurassic carbonates drilled on Leg 79 has forced us to use indirect methods, such as lithostratigraphic correlation with onshore sections, sedimentation rates, and comparison with other North Atlantic marginal basins, in assigning ages to some of the penetrated sequences. A further shortcoming of our study arises from the failure of Leg 79 to drill the site designated MAZ-8, situated on the shallow outer shelf of the Mazagan Plateau; this site would have provided valu- 
able information about the development of the outer shelf and the source of the carbonate detritus shed into the basin.

A detailed petrographic study of the carbonate facies encountered in Leg 79 sites is presented by Steiger and Jansa (this volume). The additional petrographic data discussed in this paper are graphically summarized in Figures 3,7 , and 13 . later. The regional study incorporates data collected by Jansa during fieldwork in Morocco. W. B. F. Ryan kindly supplied dredged samples from the Mazagan Plateau and U. von Rad permitted a study of the samples collected by dredging during the Meteor Cruise 46 (Wissmann and von Rad, 1979).

\section{STRUCTURAL SETTING AND LOCATION OF SITES}

The Moroccan margin has a varied physiography. The shelf width varies from $13 \mathrm{~km}$ at Cap Rhir to about $80 \mathrm{~km}$ off southern Morocco (Spanish Sahara). The shelf break in general occurs around a water depth of $150 \mathrm{~m}$; the break between slope and rise increases in depth from $1500 \mathrm{~m}$ at the island of Fuerteventura to $4000 \mathrm{~m}$ off Cap Cantin.

The margin is a structurally and tectonically complex feature and was subdivided by Hinz et al. (1982) into five segments. The most northerly Rif and pre-Rif segment is formed by nappes thrust during the Cenozoic over older sedimentary sequences of the margin and oceanic basin (Fig. 1). To the south, the Mazagan Plateau segment is an offshore extension of the Moroccan Meseta; this interpretation is supported by geophysical data which show continental crust $25 \mathrm{~km}$ thick underlying the Plateau. The crust rapidly thins under the continental rise to $5 \mathrm{~km}$ (Hinz et al., 1982). Seismic data and dredging of the Mazagan Escarpment (Renz et al., 1975; Wissmann and von Rad, 1979) have confirmed that the Plateau is underlain by a Mesozoic carbonate platform covered by Upper Cretaceous and Cenozoic hemipelagic clays, marls, and clastic sediments. To the south of the Mazagan segment lies the Essaouira segment, which represents an offshore extension of the onshore Essaouira Basin, where Traissic and Jurassic rocks are exposed in salt-cored anticlines along its eastern side. DSDP Legs 41 and 50 sites are situated offshore of the Essaouira Basin. The Essaouira segment is bordered on its southern side by the Tafelney Plateau, which according to Hinz et al., (1982) is a product of epeirogenic uplift of the western Atlas during the Late Cretaceous (FaureMuret and Schoubert, 1971; Bhat et al., 1975). Lower Cretaceous sediments beneath the Plateau are highly deformed (Hinz et al., 1982).

The dominant structural trend of the deeper part of the margin is a zone of salt diapirs trending southsouthwest-north-norhteast, which starts southeast of Fuerteventura and continues northward beneath the preRif nappes (Lehner and de Ruiter, 1977; Fig. 1). The diapiric zone extends into onshore basins, with salt extruded at the surface in the Essaouira Basin (Jebel Amsitten diapir). Based on geologic evidence provided by the results from Site 544 (site chapters, this volume) and from the geophysical evidence (Lehner and de Ruiter,

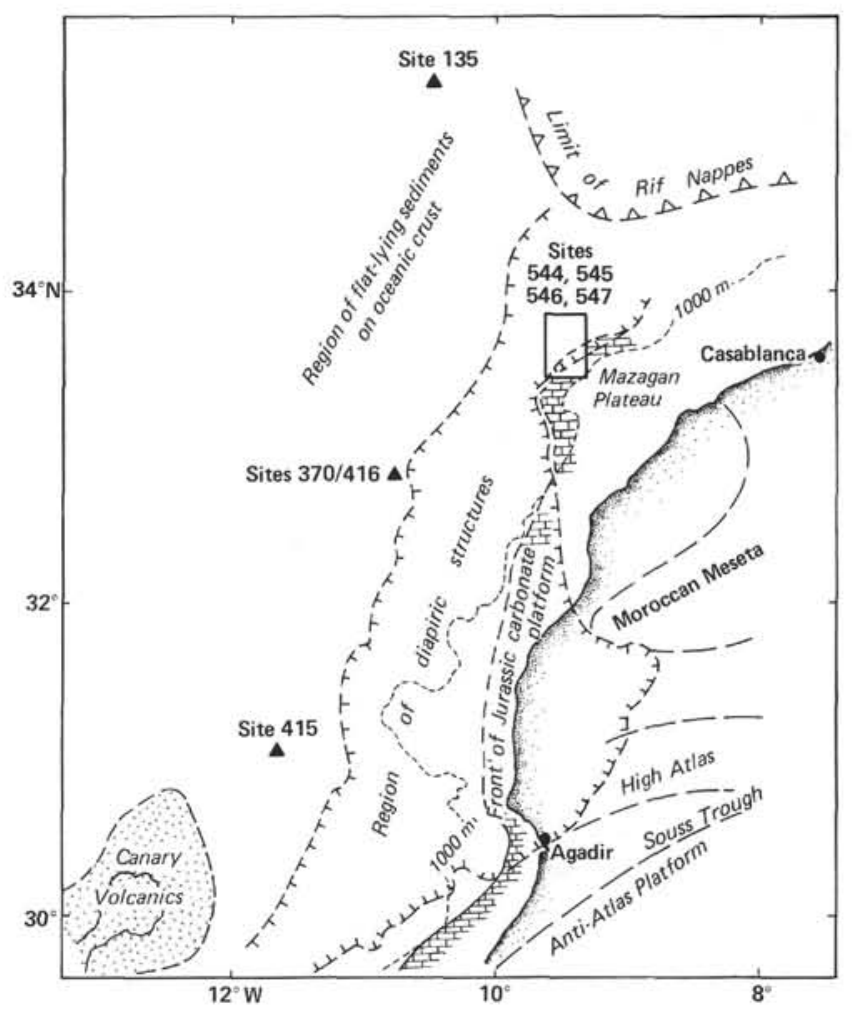

Figure 1. Location map indicating the regional geologic setting of the Mazagan Plateau on the Northwest African margin. Leg 79 sites are located within square (Fig. 2). Regional distribution of salt diapirs and carbonate platform front is adopted from Hinz et al. (1982).

1977), we consider the salt diapir province to be underlain by continental crust as indicated by the results from sites 546 and 544 (site chapters, this volume). Seaward of the diapiric zone, deep-reflection seismic profiles show that the oceanic basin is underlain by oceanic crust, with a sedimentary cover about $2 \mathrm{~km}$ thick (Lancelot, Seibold, et al., 1979).

The Leg 79 sites are situated along the slope seaward of the Mazagan Plateau, with the shallowest site (545) located at the toe of the steep Mazagan Escarpment, where water depth is $3150 \mathrm{~m}$. The detailed bathymetric map of the area by Auzende et al., this volume; see also Fig. 2) shows that an extension of the Mazagan Plateau plunges to the northwest toward Site 544, which was drilled in a water depth of $3607 \mathrm{~m}$. Site 547 is located at the base of the slope in a topographic embayment, in $3938 \mathrm{~m}$ of water. Site 546 was located on a seismic high about $15 \mathrm{~km}$ west of Site 544; it penetrated evaporites under a thin cover of Lower Cretaceous and Miocene sediments. Site 546, which was drilled in $3590 \mathrm{~m}$ of water, is not discussed here since Mesozoic carbonates or their age-equivalent deposits are missing (see Site 544 site chapter, this volume).

\section{JURASSIC-CRETACEOUS CARBONATE SEQUENCES OFF THE MAZAGAN PLATEAU}

The carbonate sequences penetrated by Leg 79 are discussed below from the shallowest site, Site 545 , to the 


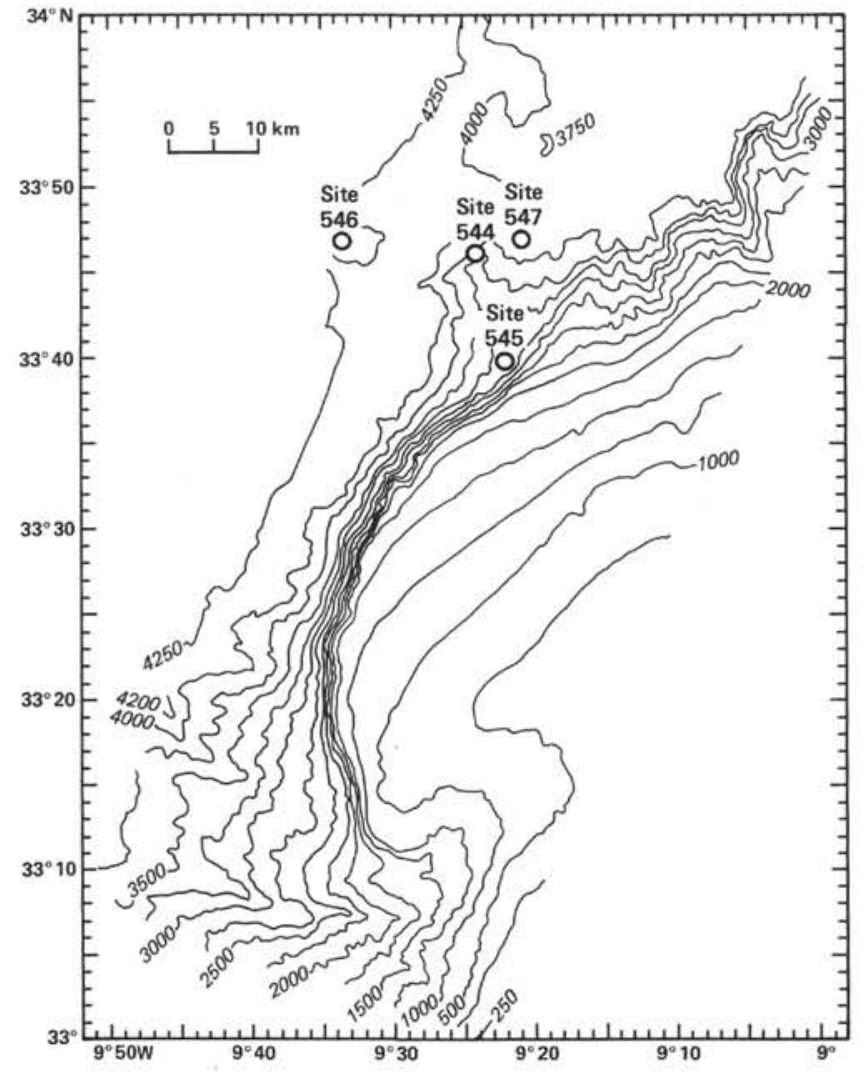

Figure 2. Location of Leg 79 sites. Bathymetry according to Auzende et al., this volume.

deepest, Site 547 (Fig. 2). The lithostratigraphic subdivisions used here correspond to the subdivisions recognized in site chapters, but a more detailed subdivision of limestone units in Sites 545 and 547 is presented here (Fig. 3, and Figs. 7 and 13, later).

\section{Site 545}

Site 545 was chosen at the foot of the Mazagan Escarpment (Fig. 2), where the multichannel seismic reflection profile (Meteor 53-08) showed only a thin onlapping wedge of younger deposits. The water at Site 545 is 3150 deep, and the sedimentary section penetrated is $701 \mathrm{~m}$ thick. Reddish pelagic limestones of Oxfordian age had been dredged some $10 \mathrm{~km}$ to the southwest by Renz et al. (1975) in water depths of 2600-3300 m, and it was expected that similar lithologies might be encountered at Site 545; drilling proved otherwise.

\section{Stratigraphic Resumé}

Four major lithostratigraphic units were recognized at Site 545. Units I to III are pelagic and hemipelagic Cenozoic to Cretaceous slope deposits which overlie a Jurassic carbonate platform (Unit IV).

Yellowish brown, very clayey, interbedded foraminiferal-nannofossil-rich ooze and clay, which extend from the sea floor to $181 \mathrm{~m}$ sub-bottom, dominate Unit I. Four intercalations of limestone gravel in the lower part of the unit were emplaced by gravity mass flows from the adjacent Mazagan Escarpment. Unit $\mathrm{I}$ is late Mio- cene to early Pleistocene in age (see site chapter), and a hiatus separates the unit from the underlying beds of Unit II. Unit II (181-252 m sub-bottom) consists of 71 $\mathrm{m}$ of conspicuously bioturbated greenish gray, yellow green, and olive, clayey, foraminiferal-nannofossil chalk and nannofossil-rich claystone. A siliceous component is provided mainly by radiolarians. Several horizons of clast-supported intraformational conglomerate occur in Cores 25 and 26 , emplaced by occasional subaqueous mass movement down the slope. The presence of pelagic foraminifers indicates that deposition occurred above the foraminiferal lysocline. Unit II is early to middle Miocene in age and is separated from the underlying sequence by an unconformity.

The Cretaceous System at Site 545 (Unit III, 252$530.6 \mathrm{~m}$ sub-bottom) is represented by $278.6 \mathrm{~m}$ of mostly green, gray, and olive nannofossil claystones and clayey nannofossil chalks. Matrix- and clast-supported conglomerate intercalations, interpreted as debris flows, and the increasing degree of tectonic disturbance downward through the unit emphasize the slope setting of Site 545 . Unit III has been dated as late Aptian to late Cenomanian (see site chapter, this volume). At the base of the unit is a yellowish gray, dolomitic claystone, $9 \mathrm{~m}$ thick, which unconformably overlies supposed Upper Jurassic limestones of Unit IV (see below).

The hemipelagic sediments of Unit III were generally deposited well above the CCD. Abundant bioturbation indicates well-oxygenated bottom waters, except during the deposition of two thin, fissile, black claystone intervals toward the middle of the unit. The seafloor at Site 545 lay above the zone of poorly oxygenated water which characterized the central North Atlantic during the midCretaceous (Arthur and Schlanger, 1979; Jansa, Enos, et al., 1979; Dean et al., 1979). The Cretaceous claystones and chalks are underlain by Unit IV, $170 \mathrm{~m}$ thick and consisting mainly of light gray, olive gray, yellowish gray, orange, and yellowish brown limestone. Poor core recovery-less than $10 \%$ in the upper part of the unitand a paucity of biostratigraphic data make the interpretation of this unit rather speculative. On the paleontological evidence presented in the site chapter by Fenton (this volume), Unit IV is considered to be Middle to Late Jurassic in age.

\section{Limestones of Unit IV}

For ease of description, we divide Unit IV into three subunits: IVA1; IVA2; and IVB. The boundaries between subunits are transitional and their selection is rather arbitrary. The petrographic constituents of the limestones are listed in Figure 3. The subunits are described in stratigraphically ascending order.

\section{Subunit IVB (Core 68 to base of Core 75; 635.5-701 m sub-bottom)}

Subunit IVB equates with the sandy limestone facies of Steiger and Jansa (this volume); it is $65.5 \mathrm{~m}$ thick and composed of sandy skeletal peloid packstones, subordinate sandy grainstones, minor oolitic grainstones, calcitic sandstones, and shale (Fig. 4A-C). Terrigenous content decreases upward and is accompanied by a color 


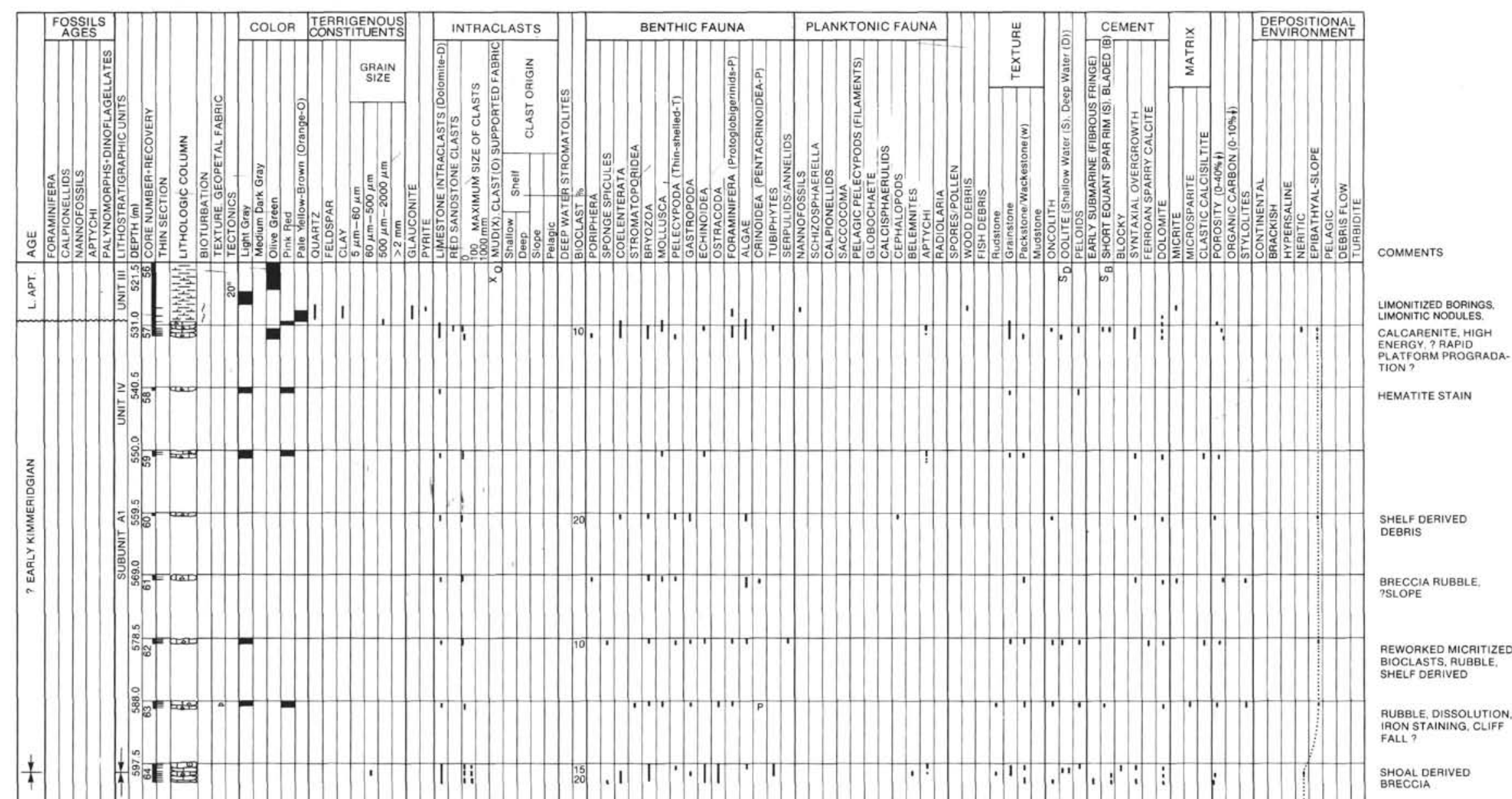




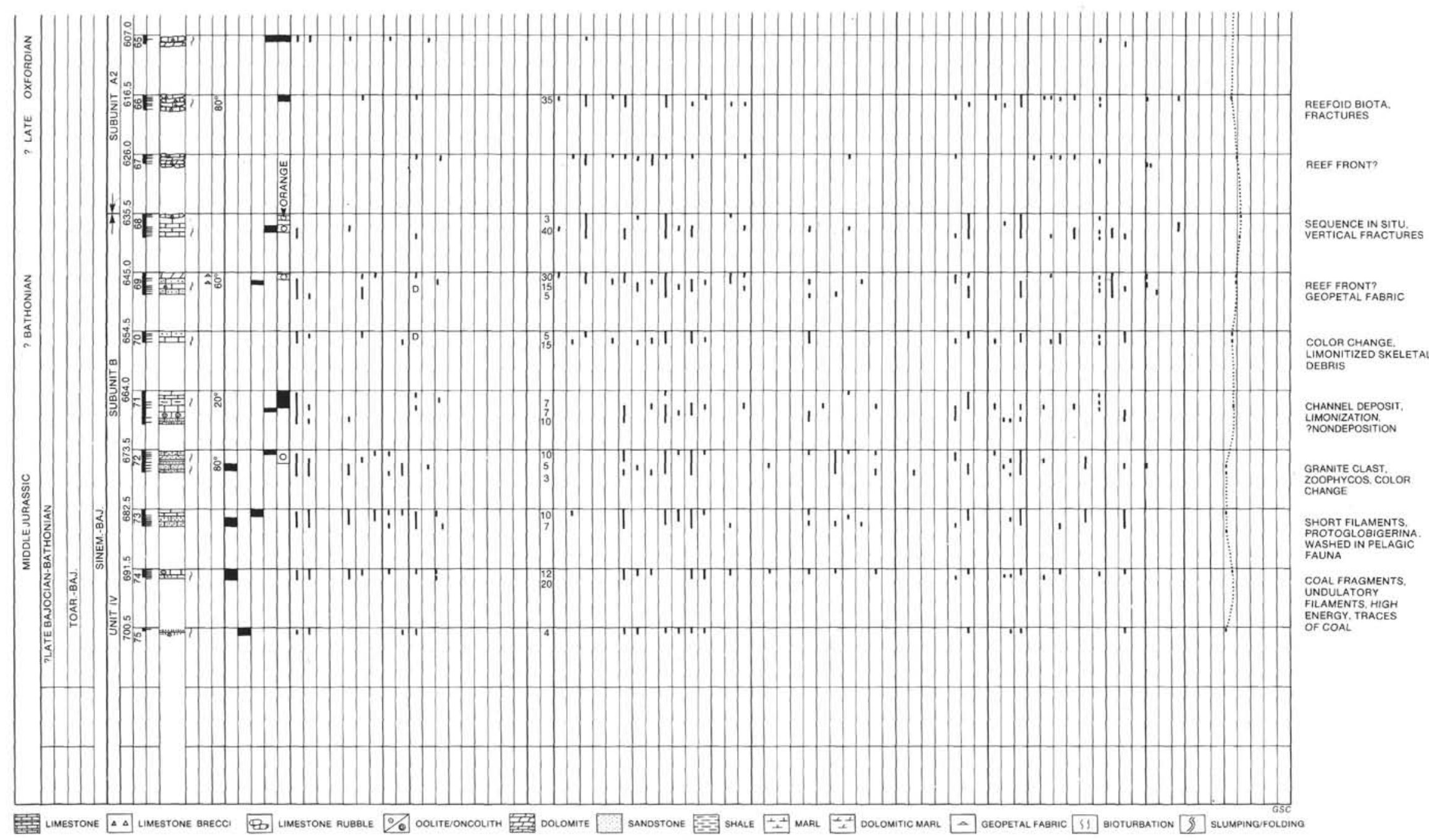

Figure 3. Geologic chart for limestone sequence at Site 545. Plot shows lithology, unit boundaries, ages, and interpreted depositional environment. Composition and textural parameters of the limestones derived from thin-section studies. 

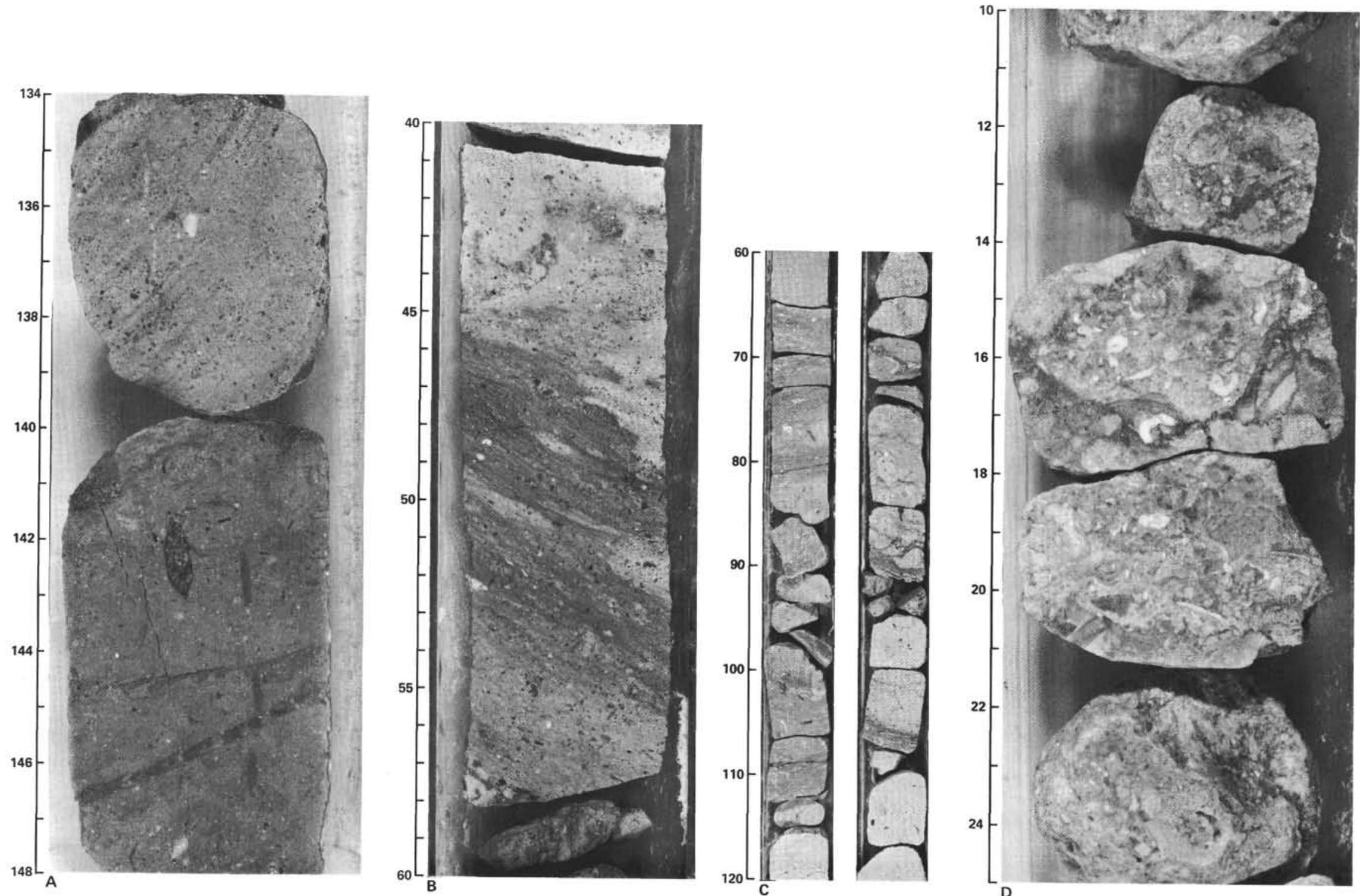

Figure 4. A. Sandy limestone with Zoophycos trace fossils (Subunit IVB); Sample 545-72-2, 134-148 cm. B. Sandy limestone with coarse sand-sized grains of quartz and feldspars floating in the carbonate. Note crinoid fragments and concentration of argillaceous matter in laminae by stylolites. Bioturbation is faintly visible (Subunit IVB). Sample $545-70-1,40-60 \mathrm{~cm}$. C. Skeletal wackestone with pseudonodular texture (Subunit IVB), Samples 545-69-1, 60-120 cm, and 545-69-2, 60-120 cm. D. Coarse-grained skeletal packstone (Subunit IVA2). Sample 545-66-1, 
change in Core $72-2$ from medium light gray to pale yellowish orange (Fig. 3).

The bioclastic component of the limestones consists of both the remains of benthic and fairly shallow water organisms (echinoids, gastropods, thick-shelled bivalves, red algae, and benthic foraminifers, Fig. 5B) and a pelagic assemblage of pelagic pelecypods (filaments), radiolarians, protoglobigerinids, Schizosphaerella, and small ammonites. Terrigenous grains are scattered through the limestones (Fig. 4A) but locally are concentrated into thin layers (less than $5 \mathrm{~cm}$ ), some of which have sharp bases. These grains are angular to subangular and consist of stretched metamorphic quartz, gneiss and phyllite fragments, weathered plagioclase, orthoclase, and microcline; they clearly demonstrate a regionally metamorphosed source at no great distance. Some sandy layers contain a variable admixture of skeletal and oolitic material (Fig. 5A) and occasionally sand-sized intraclasts of fine crystalline dolomite; skeletal wackestone and micrite are also present. Wood fragments and glauconite grains occur toward the base of this subunit. The lithologic boundary between Subunits B and A is gradational and was placed where the occurrence of terrigenous grains in the limestones (Fig. 3) diminished.

\section{Subunit IVA (545-56-7, $20 \mathrm{~cm}$ to base of Core 67; 530.7-635.5 m)}

Petrographic study of the limestones showed that Subunit A is composed of two distinct sequences; thus it was further subdivided into IVA1 and IVA2 (Fig. 3).

\section{Subunit IVA2 (Section 545-64-2 to base of Core 67; 599.0-635.5 m sub-bottom)}

Subunit IVA2 consists of white to yellowish gray limestones with reddish mottling. It has larger lithofacies diversity than Subunit IVB: skeletal packstones (Fig. 4D) and grainstones, oolitic grainstones (Fig. 5C), skeletalintraclast grainstones, and very fine grained peloid packstones (peloidal calcisiltites) all occur. This subunit is characterized by the presence of coral debris such as the colonial Thamnasteria and branching phaceloid forms such as Thecosmilia (Fig. 5D). Bivalve, gastropod, bryozoan, ostracode, and echinoid remains comprise much of the remaining skeletal debris; less common are Pentracrinites ossicles, Tubiphytes, foraminifers, sponge and dasycladacean algae debris. Ammonites, belemnite fragments, and Chaetetopsis are rare. The skeletal debris displays varying degrees of micritization. Other grain components of the limestones are coated grains, grapestones, and rounded intraclasts (maximum $3 \mathrm{~cm}$ in diameter) of silt-sized peloid packstone, skeletal-peloid packstone and grainstone; some intraclasts enclose ooids, oncoids, and other algal debris.

Brecciated zones in Subunit IVA2 contain angular limestone clasts, frequently bounded by stylolites and surrounded by reddish dolomite matrix. The intensity of dolomitization increases progressively upward in Subunit IVA2, and locally reaches $100 \%$. Two types of dolomites are present. The first type consists of coarse dolomite rhombs which have replaced the skeletal grains and intraclasts (Fig. 5B) and are commonly associated with stylolitization. The other type of dolomite is represented by dark, yellowish orange dolomicrosparite which is in places laminated, with pyrite concentrated in some of these laminae. The thick, laminated dolomite in Section 545-67-1 drapes coral debris at its base and, as suggested in the site chapter, probably represents the filling of a large cavity. However, Steiger and Jansa (this volume) suggest that stromatolite origin cannot be excluded for the laminated dolomite.

\section{Subunit IVA1 (545-57-7, $20 \mathrm{~cm}$ to base of Section 545-64-1; 530.7-599 m sub-bottom)}

Core recovery of Subunit IVA1 was less than $10 \%$, which makes interpretation of the lithology of this subunit particularly difficult. The limestones fragments recovered are 2 to $10 \mathrm{~cm}$ in size, and different lithologies are juxtaposed in the core barrel. This variability either could be the result of drilling or could reflect true lithological variability in the penetrated beds; we assume that the latter is the case.

Subunit IVA1 is only $8.3 \mathrm{~m}$ thick and comprises mainly light gray, variably dolomitized skeletal intraclast grainstones and packstones (Figs. 5C, 6C). Skeletal grains are similar to those of Subunit IVA2, except that only rare coral debris occurs, whereas dasycladacean algal debris increases to become very common near the top of the subunit. Another difference is that the skeletal grains are more highly micritized than in Subunit IVA2; this in places has rendered them indistinguishable from interclasts of structureless cryptocrystalline carbonate. Dolomitization is also more pronounced, and the skeletal grains and intraclasts are replaced by coarse dolospar; locally, dolospar forms cement (Fig. 6C). Porosities have been visually estimated to vary between 15 and $35 \%$ for this subunit. Preserved small patches of micrite between some of the skeletal grains and the loose packing of the grains suggest that the limestone was originally a packstone and the matrix was leached out during diagenesis. The resulting open fabric was only partially infilled by dolospar; this poor cementation may explain the poor recovery of the subunit.

\section{Depositional Environment}

The interpretation of sedimentation conditions for the limestone recovered at Site 545 is difficult not only because of poor core recovery, but also because of the almost complete lack of biostratigraphic data and the strong late diagenetic overprint. Because the detailed petrographic examination of the limestones in Unit IV did not allow us to narrow down their origin, a broad comparative study of dredged limestones from the Mazagan Escarpment and Jurassic limestones outcropping in the Essaouira Basin was undertaken. Such information provided not only data about the regional development of the Jurassic carbonate sequences on the Moroccan margin, but also indirect evidence about the age of the carbonates encountered at Site 545 .

The limestone sequence is discussed in stratigraphically ascending order. The dominance of peloid packstones and grainstones in Subunit IVB might suggest a shelf-lagoon environment. The freshness of the feld- 

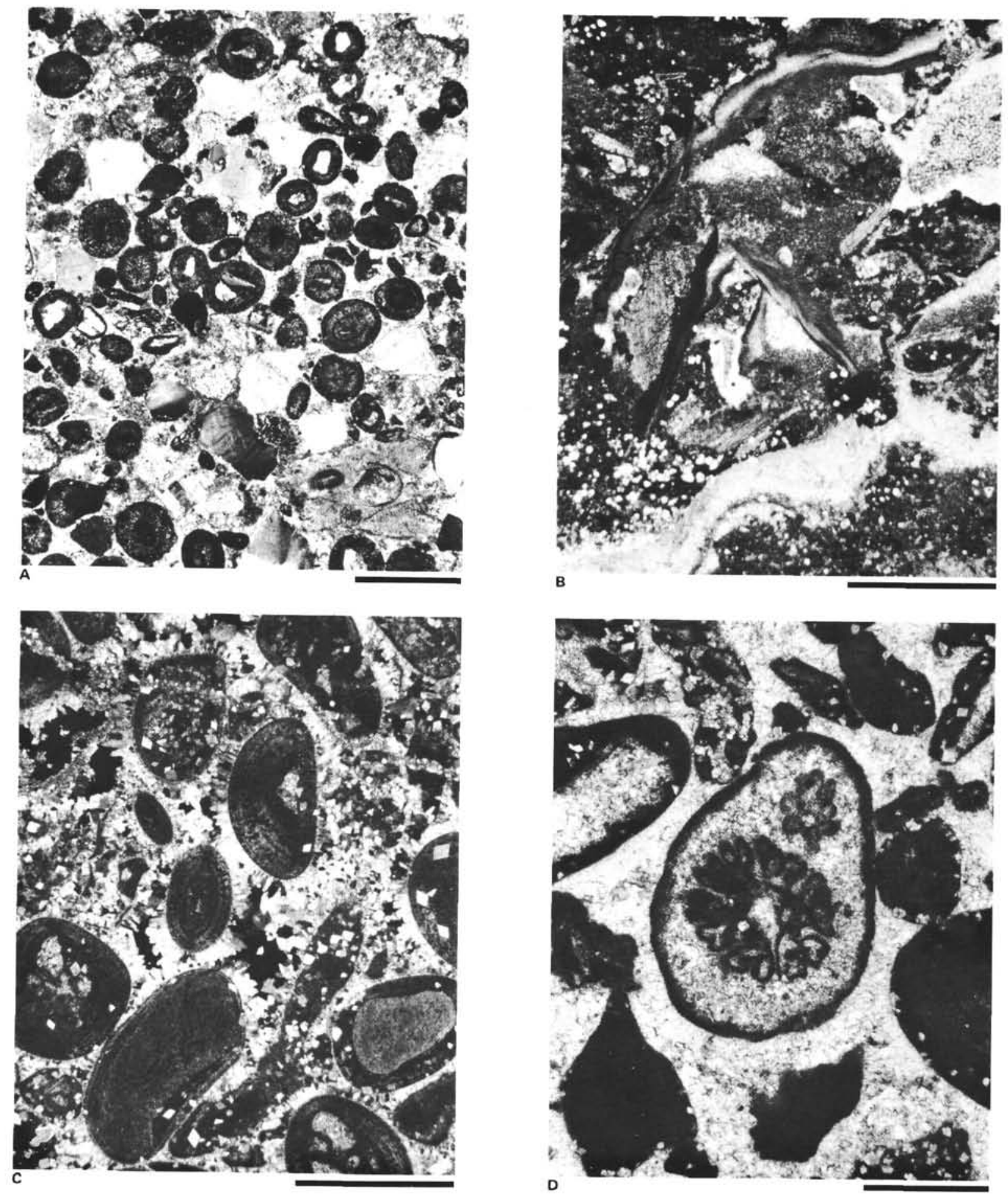

Figure 5. A. Sandy oolitic packstone cemented by microsparite. Quartz and feldspar grains are subangular in shape; some of the clastic grains form nuclei of the oolites. Debris of echinoids and thick-walled mollusk shells is rare. Sample 545-75-1, 3-7 cm, thin section, crossed nicols, scale bar $1 \mathrm{~mm}$. B. Skeletal packstone with coarse debris of mollusks, echinoids, and peloid packstone intraclasts. Coarse dolospar crystals replace some of the bioclasts. Geopetal fabric developed in shelter cavities. Sample 545-69-1, $89-93 \mathrm{~cm}$, thin section, crossed nicols, scale bar $1 \mathrm{~mm}$. C. Oolitic grainstone, with grains cemented by rims of bladed, sparry calcite. Some of the oolites were broken and reworked. Incomplete cementation preserved high interparticle porosity. Sample 545-64$1,62-66 \mathrm{~cm}$, crossed nicols, scale bar $1 \mathrm{~mm}$. D. Abraded intraclasts of coral fragments rimmed by micrite envelopes in a limestone conglomerate. Pebbles are cemented by bladed, isopachous, sparry calcite. Sample 545-64-2, 23-26 cm, thin section, plane light, scale bar $1 \mathrm{~mm}$. 

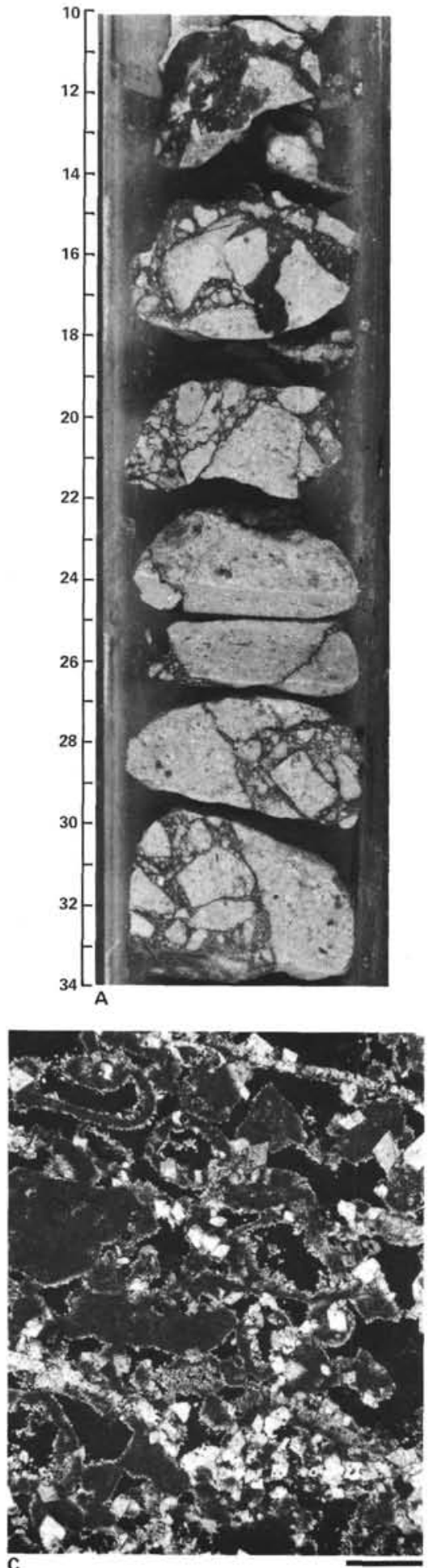
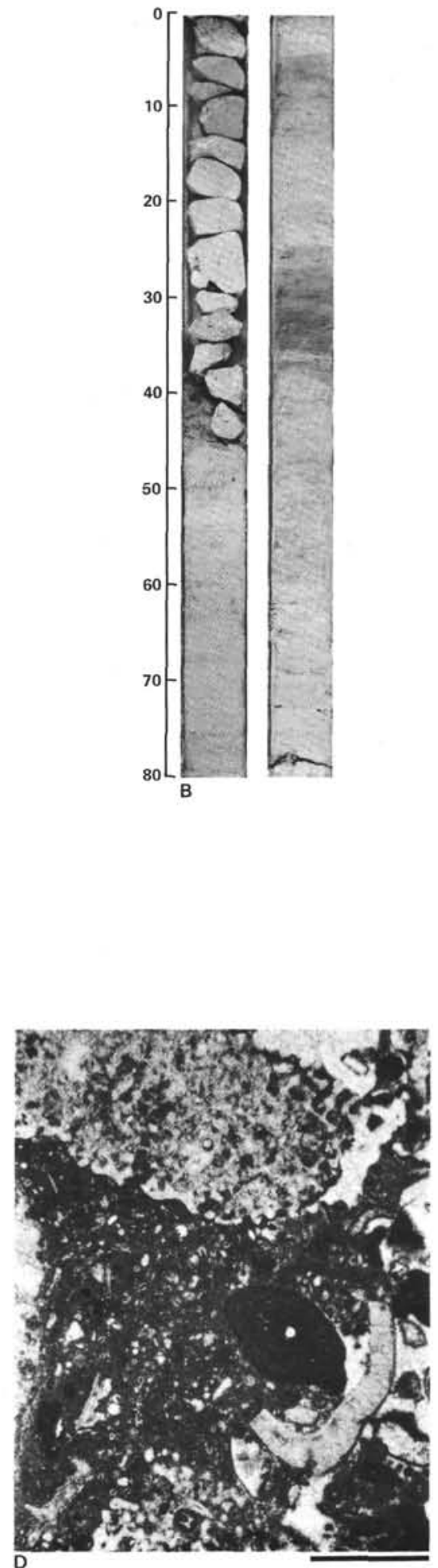

Figure 6. A. Limestone breccia with clasts cemented by a mixture of sparry calcite and dolospar. Microscopic study of the cements indicates that cementation occurred in a fluctuating freshwater phreatic and mixed zone. Note angular shape of limestone clasts (Subunit IVA1). Sample 545-64-1, $10-34 \mathrm{~cm}$. B. Limestone clasts of a debris flow deposited in upper Miocene clayey nannofossil ooze. Samples 545-20-1, 0-80 cm, and 545-20-2, $0-80 \mathrm{~cm}$. C. Weakly cemented intraclast-skeletal grainstone. Note high chalkification of bioclasts; some of them are preserved only as micrite envelopes. Clasts have an irregular rim of microspar and are cemented by micrite. Coarse, euhedral, dolomite crystals replace some of the bioclasts and also form a cement when a single crystal penetrates two adjacent carbonate grains. Intra- and interparticle porosity is high (25-30\%) and is the result in part of leaching. Sample $545-57-1,25-31 \mathrm{~cm}$, thin section, crossed nicols, scale bar $0.5 \mathrm{~mm}$. D. Limestone clast enclosed in Miocene debris flow contains common calpionellids (Calpionella alpina, Crassicularia) that demonstrate the late Tithonian age of the limestone (Azema and Jaffrezo, this volume). Note also the presence of Tubiphytes. Such limestones were not penetrated in situ at Site 545; however, their occurrence in younger debris flows indicate that Upper Jurassic limestones outcrop near the edge of the Mazagan Plateau. Sample 545-15-1, $24-26 \mathrm{~cm}$, thin section, crossed nicols, scale bar $1 \mathrm{~mm}$. 
spars, angularity of the clastic grains, and mineralogy of the terrigenous component indicate proximity of the depositional site to a rapidly eroding metamorphic terrain. Coal fragments, the occasional presence of laminae and layers of terrigenous clastics, presence of oolitic grainstones, and admixture of oolites with terrigenous grains as nuclei (Fig. 5A, C) suggest an inner-shelf, high-energy depositional environment. Faunal remains such as the thick-walled mollusk, echinoids, benthic foraminifers, and blue-green algae encrustations support shallow-shelf origin. However, in addition to the shallow-shelf faunal assemblage, a pelagic assemblage, including pelagic foraminifers (protoglobigerinids), pelagic pelecypods (filaments), juvenile ammonites, and Zoophycos burrows, are found mixed with the shallow-water assemblage near the base of the limestone sequence. The fossils clearly indicate mixing of pelagic and relatively shallow nearshore facies. Such mixing can be explained by deposition at a narrow, steep shelf, or it may indicate development of an inclined carbonate platform (ramp) (standard facies belt 6 of Wilson, 1975). There was no obstruction to the open oceanic water flooding the "shelf," which can be interpreted as indicating absence of reefs or shelf-edge shoals during this period. The decrease of terrigenous detritus stratigraphically upward (Fig. 3) points to deposition of Unit IVB during a transgressive period.

Further diminished content of terrigenous grains in Subunit IVA2 and the disappearance of pelagic fossils suggest changes in the carbonate margin morphology. Fragments of reef-building biota such as corals, sponges, Tubiphytes (Figs. 5D, 6D), and serpulids mixed with intraclasts of peloid packstones and limestones with oncolites, oolites (Fig. 5C), and green algae debris indicate that conditions favorable for the evolution of bioherms were established near the shelf edge. The shelf-derived intraclasts mixed with the reef-derived rubble, together with lack of pelagic biota, indicate that deposition occurred on the landward side of the paleoshelf edge. If such an interpretation is correct, then the facies change reflects outward and upward building of the carbonate platform during this period.

Recognition of the presence of coral bioherms near the paleoshelf edge is important for constraining the age of the sequence. Coral bioherms are known from the Essaouira Basin, where they occur in the upper Oxfordian Lalla Oujja Formation (Adams, 1979), as will be discussed in more detail later.

The origin of the uppermost Subunit IVA1 is the least clear, mainly because the limestone in this subunit underwent a period of intensive leaching and dolomitization which obscured its original fabric and composition (Fig. 6C). The presence of intraclast-skeletal grainstones would indicate high-energy depositional conditions. However, as already mentioned, some of the limestones show traces of carbonate mud between skeletal grains. This may indicate that the original limestone had a packstone or, in places, a wackestone fabric, and that the micrite matrix was removed during leaching by undersaturated fresh water.
Rocks similar to those of Subunit IVA1 were observed by Adams (1979) in onshore Morocco in the Essaouira Basin, where they occur in the middle part of the Ouanamane Formation. According to Adams, these bioclast-intraclast wackestones and packstones exhibit textural inversion and were formed during a period of storms which carried the coarse, skeletal grains into protected, low-energy lagoons. However, the skeletal composition of the limestones of Subunit IVA1 shows a higher variability than those described by Adams (1979); they reflect open, deeper, shelf conditions.

A conspicuous feature of the limestones of Subunit IVA1 is the chalky appearance of bioclasts (Fig. 6C; the clasts are a whitish color in reflected light). Similar chalkification of skeletal grains has been observed in relatively shallow lagoons of the Jurassic in the Paris Basin (Cussey et al., 1982) and in some Miocene reefs of Indonesia (observation by Jansa). The timing of chalkification is not well established, but the presence of micritized grains in intraclasts found in Hole 547B (Fig. 7, later) suggests that this process was active during the Late Jurassic.

The micritization, leaching, and dolomitization are closely related in time. Micritization precedes leaching, and leaching produces an intergranular and intraparticle porosity that increases up the section with the increasing dolomitization and micritization. The lowest part of the upper Aptian chalks that unconformably overlie Jurassic limestones is also completely dolomitized. The occurrence of dolomitization above the unconformity may indicate that the dolomitization was late and perhaps continued into the Aptian. The micritization, by contrast, had to be either syndepositional or an early diagenetic feature. Leaching and development of intergranular porosity are postdepositional features, probably synchronous with development of the unconformity which separates the top of the limestones from the Aptian chalks, but they predate the dolomitization.

The uppermost surface of the limestones of Subunit IVA1 lacks any indication of borings, development of a hardground, or Fe-Mn coatings that otherwise are common on exposed surfaces of limestones on the Mazagan Escarpment; thus we interpret the limestone surface to be erosional. The timing of this erosion probably was after the Berriasian but before the Aptian, as similarly observed in coastal basins of Morocco (Jansa and Wiedmann, 1982; Wiedmann et al., 1982).

We concluded that the limestones of Subunit IVA1 originated in a shelf-lagoon. The uncertainty that remains is whether the shelf-derived carbonate grains were deposited near the shelf edge during a regressive period, or deposited rapidly on the upper slope. The lack of pelagic biota in limestones of Subunit IVA1 argues against slope deposition, but the presence of the carbonate escarpment almost $1000 \mathrm{~m}$ high landward of Site 545 strongly suggests that the site of deposition should be the upper slope. The only explanation of this contradiction is that the escarpment was tectonically modified after Jurassic time. We will return the origin of Subunit IVA1 after discussing the ages of limestone sequences 
and the composition of limestone intraclasts in Miocene debris flows, which provide additional information on the younger part of the Mazagan Escarpment.

\section{Age}

Biostratigraphic evidence for the age of limestones in Unit IV is minimal. Sample 545-74-1, $36 \mathrm{~cm}$ was dated by nannofossils as Toarcian-Bajocian (M. K. Cooper, pers. comm., 1983); Core 73 was dated by palynology as Middle Jurassic (E. Davies, pers. comm.) and as Sinemurian-Bajocian by Fenton (this volume). Microfossil assemblages including protoglobigerinids (Cores 73 to 70 ), filaments (Cores 74 to 68), and Schizosphaerella (Cores 74 and 72 ) are characteristics of the Middle to (?)early Late Jurassic in the Mediterranean region and in the central North Atlantic. Assuming that the typical Kimmeridgian Saccocoma microfacies (Jansa, Enos, et al., 1979) is missing at Site 545 because of an age break and not because of facies change, we can speculate that Unit IV is probably older than Kimmeridgian.

The sequential transition from terrigenous clastics to limestones is a characteristic feature of the Middle Jurassic around the North Atlantic, including western Morocco (Ambroggi, 1963; Jansa and Wiedmann, 1982; Jansa and Wade, 1975; Bhat et al., 1975). The Ameskhoud Formation of the Essaouira Basin of onshore Morocco is Bathonian in age according to Ambroggi (1963) and confirmed by Ager (1974). This formation consists of coarse-grained continental clastics intercalated with reddish shales, which are transgressively overlain by a deepening carbonate sequence. The basal carbonates are oolitic and oncolitic at Jebel d'Anklout. In the Jebel Amsitten area, this carbonate sequence was named the Ouanamane Formation by Adams (1979); it comprises grainstones grading upward into packstones and wackestones. The limestones contain up to $12 \%$ terrigenous grains which are mixed with intraclasts, bioclasts, and ooids and are similar in composition to Subunit IVB. The Ouanamane Formation is Bathonian to mid-Oxfordian in age and is overlain by the upper Oxfordian Lalla Oujja Formation, which is characterized by the presence of highly dolomitized coral bioherms (Jurassic reefs of Ambroggi, 1963) rich in corals, oysters, echinoderms, and sponges, similar to those found in the limestones of Subunit IVA2. The Lalla Oujja Formation is overlain by pelleted mudstones and packstones, with algal stromatolites and brecciated horizons which are in part or completely dolomitized. Such horizons were explained by Adams (1979) as representing collapse breccias formed by dissolution of evaporites. He named this sequence the Iqqui el Bahar Formation. It is early Kimmeridgian in age and like the Subunit IVA1 breccia horizons, is strongly dolomitized; however, it has a less diverse fauna. Considering all the available evidence, we conclude that Unit IV in Site 545 is most likely Bajocian to Oxfordian in age.

\section{Limestone Debris in the Gravity Flows of Unit I}

Four horizons of limestone lithoclasts were found intercalcated within upper Pliocene to upper Miocene yellowish brown, clayey foraminiferal ooze (Cores 10,15 ,
16, and 20) at Site 545. The limestone debris occurs either as pebbles mixed with clayey foraminiferal ooze in horizons 10 to $20 \mathrm{~cm}$ thick (Fig. 6B) or as accumulations of limestone fragments in beds up to $3 \mathrm{~m}$ thick that lack an intervening carbonate mud matrix. The horizon in Section 545-16-1 shows internal homogeneity in the composition of the limestone, which may indicate that it was derived from a single limestone block that tumbled down the slope. Drilling may have fragmented limestone, particularly if it was bedded. In contrast, limestone fragments in other beds are petrographically variable, with well-rounded to subangular pebbles 1 to 5 $\mathrm{cm}$ in size. Some of the pebbles have boring bivalve crypts on their exterior, suggesting that the pebbles were originally located in shallow water and were exposed for some time on the sea bottom. The redeposition and multiple origin of some of these pebbly horizons is documented by a limestone breccia bed in Core 15 , which is composed of pebbles of limestone conglomerate in which Upper Jurassic clasts are embedded in a micrite containing Late Cretaceous planktonic foraminifers (Globotruncana sp. cf. $G$. sigali; site chapter, this volume). Thus gravity displacement of clasts first occurred during the Late Cretaceous, with a second period of reworking and gravity flow during the late Tertiary.

Petrographically, the lithoclasts in the Miocene debris flows are highly variable (Steiger and Jansa, this volume) but can be subdivided into three groups.

1. Light gray skeletal-intraclast wackestones and packstones, which contain shallow-water fossils such as debris of mollusks, bryozoans, echinoderms, lithistid sponges, foraminifer tests, traces of Globochaete and frequent calpionellids (Fig. 6D). Peloids, oncoliths, reworked ooids, and rounded intraclasts of skeletal-peloid packstone and wackestone are the additional limestone components. Limestone debris, particularly in Core 15 , is similar in composition to limestones found at the top of the in situ limestone sequence (Unit IVA1) at Site 545. Fauna in the clasts points to deposition in a deeper shelf environment at the outer edge of the Mazagan platform, where carbonate deposition continued into the earliest Cretaceous.

2. Grainstones that are similar in composition to the first group except for the additional occurrence of ooids, scleractinian corals, silicified sponges, and rare red algal debris. The bladed and cloudy isopachous rim calcite cements document an early submarine cementation of the grainstones. These sediments were deposited in a high-energy environment near the paleoshelf edge of the Mazagan Plateau.

3. Pink-colored skeletal and oncoid packstones containing echinoderm debris and thin-shelled bivalve debris (filaments), sponge fragments, and fragments of Sacoccoma, suggesting the existence of a deeper shelf environment during the Kimmeridgian that was later exposed to erosion at the escarpment edge.

The presence in Section 545-18-1 of a slightly argillaceous, silty, peloid-skeletal packstone and glauconitebearing soft microsparite, both lithologies yielding Nannoconus columnii of Berriasian to Barremian age (Thierstein, 1976; Site 545 site chapter), reveals that pe- 
lagic carbonate deposition continued on the margin into the Early Cretaceous. Onshore studies in Morocco demonstrated that carbonate deposition ended in the late Berriasian (Wiedmann et al., 1982), when an increase in water depth led to the drowning of the carbonate platform and to the deposition of marls and shales. On the Meseta, however, the continental-littoral depositional environment continued throughout the Early Cretaceous.

The calpionellid fauna found in limestone clasts that are mixed with clasts of grainstones enclosing fragments of corals and sponges indicates that coral bioherms rimmed the shelf edge from the Oxfordian to the Early Cretaceous. A similar association has been observed along the Canadian North Atlantic margin (Jansa et al., 1982).

The limestone debris flows enclosed in the upper Miocene to upper Pliocene oozes provide additional evidence that the outer edge of the Mazagan escarpment is underlain by Upper Jurassic to Lower Cretaceous limestones deposited in a moderately deep shelf environment. Absence of similar limestones in Unit IVA at Site 545 supports our interpretation that the latter unit is earlier than the Late Jurassic. The concentration of limestone debris flows in the late Miocene, which was a period of tectonic upheaval along the northwestern African margin (Lancelot, Seibold, et al., 1979; von Rad and Wissmann, 1982) and of associated volcanic activity (Cape Verde and Canary islands; Grunau et al., 1975), was accompanied by block faulting, which resulted in submarine exposure of the carbonate escarpment.

\section{Site 547}

Two holes were drilled at this site: Hole 547A, which reached a depth of $744.5 \mathrm{~m}$, bottomed in Albian claystones; Hole 547B, which was a reentry hole continuously drilled from $724.5 \mathrm{~m}$ to $1030 \mathrm{~m}$ T.D., penetrated a sequence of Jurassic limestones and bottomed in Triassic(?) red beds. The water depth at Site 547 is $3938 \mathrm{~m}$.

The drilling site was selected at the base of the slope of the Mazagan Plateau, to the northeast of a morphological high extending from the Mazagan Plateau as a northwest-trending spur (Fig. 2). Site 544 was located on the western side of this spur and encountered Paleozoic basement. The bathymetric map of the Mazagan Plateau (Auzende et al., this volume) shows that Site 547 is situated in the mouth of a structural trough which continues updip and disappears in the middle of the Mazagan Escarpment. The structural situation of the Site 547 area probably affected deposition, and thus the Jurassic development of Site 547 may not be representative of an open Atlantic carbonate margin.

\section{Stratigraphic Resumé}

Seven major lithostratigraphic units were recognized at Site 547 (see site chapter). The uppermost, Unit I, consists of $141 \mathrm{~m}$ of pelagic, pale yellowish brown foraminiferal ooze deposited above the foraminiferal lysocline on a well-oxygenated bottom. Unit I is Quaternary to late Miocene in age and is separated by an unconformity from $84 \mathrm{~m}$ of greenish gray clayey nannofossil ooze of middle Miocene to late Eocene age (Unit II). The underlaying units III and IV span the late Eocene to Campanian and are composed of greenish gray siliceous chalks which enclose several horizons of mud-supported debris flows and slump deposits. The clasts in the debris flow deposits consist of nannofossil claystone, chalk, and chert, all derived from pelagic to hemipelagic slope deposits. The concentration of slumps and debris flows in two distinct stratigraphic levels (late Eocene and $\mathrm{Pa}$ leocene/Late Cretaceous) probably reflects slope instability during Laramian and Pyrenean tectonic phases, which are known from the coastal basins of Morocco (Jansa and Wiedmann, 1982; von Rad and Wissman, 1982).

An unconformity separates the Campanian from $350 \mathrm{~m}$ of underlying Cenomanian through upper Albian greenish gray calcareous claystones and mudstones (Unit V). These hemipelagic deposits accumulated above the calcite compensation depth (CCD) on the continental slope. Abundant burrowing suggests that the bottom was fairly well oxygenated, which is at variance with the mid-Cretaceous of the deeper central North Atlantic Basin, where oxygendeficient conditions permitted accumulation of dark, organic-matter-rich shales (Hollister, Ewing, et al., 1972; Arthur and Schlanger, 1979; Jansa, Enos, et al., 1979).

Unit V unconformably overlies Jurassic to Lower Cretaceous limestones (Unit VI). The dominant lithologies of the 159.5-m-thick Unit VI are limestone breccias, nodular limestones, fine-grained limestone, marls, and claystones; the last are more frequent in the lower half of the unit. The limestones overlie dark gray and reddish gray sandy mudstones of Unit VII, which, near the base, contain rare argillaceous feldspathic sandstones. A total of $97.5 \mathrm{~m}$ of red beds were penetrated in Hole $547 \mathrm{~B}$, but the base of the sequence was not reached. Spores near the top of Unit VII indicate a Rhaetian or younger age (Fenton, this volume). We can thus conclude that Unit VII is Late Triassic to earliest Jurassic in age.

The lack of fossils in mudstones of Unit VII, except spores characteristic of marshy vegetation, and the presence of rare anhydrite nodules and root casts all indicate that the beds are continental deposits.

The lithologic boundary between Units VII and VI was placed by shipboard scientists (site chapter, this volume) at the base of Core 24 , because it contained the last occurrence of limestones encountered in Hole 547B. One of the assumptions for placing the base of Unit VI at the base of Core 24 was that the limestones in this core represent an in situ deposit, but this assumption has not been confirmed by thin-section study. The basal limestone in Core 24 is an allochthonous, medium gray limestone breccia, underlain by medium dark gray and grayish red, slightly calcareous mudstone, similar in composition and color to those occurring in the overlying Core 23 and the underlying Core 25 . The mudstone in Core 25 is calcareous (8.8\% carbonate) and medium dark gray, alternating with minor reddish mottled beds. Coarse dolomite crystals and anhydrite blebs are scattered in the mudstone. The reddish coloration becomes more intense downward in the hole, and in Core 26 
about $50 \%$ of the sediments are reddish brown in color. Close inspection of Core 24 shows that, except for strong disturbance of the core by drilling, there occurs in Section 547B-24-1, between 73 and $136 \mathrm{~cm}$ a smeared zone consisting of dark greenish gray oligomictic conglomerate, with a small proportion of elongate lenses and bands of yellowish brown nodular micrite in grayish red and very dusky red mudstone, similar to those of Unit VII. The "smear zone" could represent bedding thrust plane, where the still coherent snout of the slump has pushed over portions of itself (Dott, 1963).

As we will later describe, we interpret the limestone breccia in Core 24 to be allochthonous, probably representing the first limestone debris flow reaching the mud$\mathrm{dy}$ bottom of the incipient marine basin. We assume that lithologic transition between Units VII and VI is gradual and that perhaps part of the sequence at this boundary might be missing as a result of either slumping or faulting.

\section{Limestone of Unit VI}

Unit VI (547B-6-1, $107 \mathrm{~cm}$, to base of Core 547B-24; 773-932.5 m sub-bottom) has been subdivided by shipboard scientists into two subunits: the boundary, in Core 547B-14, separates the more argillaceous, darker, carbonate claystone lithofacies of subunit VIB from the overlying, principally reddish brown, and more nodular limestone lithofacies of Subunit VIA. Additional laboratory studies of cores and examinations of 170 thin sections showed considerable compositional and textural variability of sediments in these subunits and led to their further subdivision into three smaller segments (Fig. 7).

\section{Subunit VIB2 (Cores 547B-24 to 547B-20, 891-932.5 m sub-bottom)}

Subunit VIB2 is composed of medium gray to blackish gray silty mudstones and shales alternating with bioturbated olive gray micritic limestone, limestone breccia beds (Fig. 8A), nodular limestone, dolomitic shale, microcrystalline dolomite beds, and two horizons of olive black, organic-matter-rich shale that yielded up to $6.76 \%$ of organic carbon. The medium dark gray shale which occurs in beds a few $\mathrm{cm}$ to $60 \mathrm{~cm}$ thick is silty, slightly calcareous, and contains mica, plant debris, fragments of fish bones, and traces of spicules and ostracodes. The limestone breccia beds intercalated with the shale are 15 to $40 \mathrm{~cm}$ thick. The limestone clasts in the breccia beds are mostly angular to subangular (Fig. 8A), poorly sorted, bluish gray, medium gray, and olive gray. Some beds are monomictic, but others have a polymictic composition. Clasts in the breccia beds of the lower part of the subunit (below 547B-23-2, $40 \mathrm{~cm}$ ) are mostly laminated dolomites, some of which have characteristic textures of algal stromatolites, such as crinkle laminae, alternation of 0.1 - to $0.3-\mathrm{mm}$-thick, light- and dark-colored laminae (the dark laminae show minute desiccation cracks and surface erosion, Fig. 9A). The matrix in these breccia beds is argillaceous dolomicrosparite. The clasts and matrix lack fossils except for frequent spores of Classopollis sp. enclosed in the laminated dolomite clasts. The laminated dolomite was deposited in an in- tratidal and supratidal environment; its textural features are very similar to the stromatolitic dolomites outcropping in the Lower Jurassic of the Essaouira Basin (Fig. 9B).

The first marine fauna, represented by ostracodes, primitive lagenids, and rounded casts filled by sparry calcite after spicules, occurs in the limestone clasts above 547B-23-2, $40 \mathrm{~cm}$ (Fig. 9C). Above this level the composition of the clasts changes to silt-sized peloid grainstone, quartz-silty argillaceous peloid packstone, and skeletal-peloid packstones. The skeletal packstones contain debris of ostracodes, gastropods, mollusks, foraminifers, radiolarians, and spicules (Fig. 9D). Small cyanobacterian nodules and laminated dolomite clasts are present but rare. Rare fragments of ammonites, dasycladacean algae, and remains of the microfossil Schizosphaerella (Kälin and Bernoulli, this volume) were observed in clasts near the top of Subunit VIB2.

Important from an interpretative viewpoint is the presence of boundstones in Cores 20, 23, and 24. In Sample 547B-24-1, 3-10 cm, a 7-cm-thick layer of wavy and irregularly laminated peloid boundstone overlies an oligomictic conglomerate. The basal $2 \mathrm{~cm}$ of Sample 547B20-2, 63-90 cm consists of a similar lithology; the irregular top surface is foraminifer-encrusted and overlain by oligomictic conglomerate. Although these two boundstones resemble the "crusts" which repetitively cap debris flow units in Subunit VIA, their in situ development in Subunit VIB cannot be definitely confirmed. The boundstone encountered in Cores 23 and 22 differs from the cyanobacteria crust capping breccia beds. A moderate brown and grayish olive laminite, which consists of alternating layers of calcite microsparite and peloids, rests horizontally on oligomictic conglomerate (which contains phenoclasts of the laminite) and contains small Stromatactis-like disruption structures and occasional burrows. An overlying limestone displaying calcite-spar-filled polygons in a micrite matrix represents gypsiferous mud. Probable core loss separates this lithology from oligomictic conglomerate. Stromatolites associated with replaced evaporites are strong evidence for emergence, but although the internal bedding of these examples is broadly concordant with the surrounding conglomerate, their general facies association throws doubt on their being in situ.

Subunit VIB2 has been severely disturbed by tectonism. The axis of an overturned fold occurs in Section 547B-20-2, and bedding dips vary considerably, with some vertical beds in Core 21 . Because of low core recovery, it is difficult to determine if the tectonically contorted strata of Subunit VIB2 represent faulting or if the structures are the result of occasional downslope movement of still moderately soft sediments.

Subunit VIB2 is poorly dated by spores and foraminifers as Hettangian to early Pliensbachian (Fig. 7; Site 547 site chapter, and Riegraf et al., this volume).

\section{Subunit VIB1 (547B-14-2, $37 \mathrm{~cm}$ to base of Core 19; 839 to 891 m sub-bottom)}

This subunit is basically a sequence of pale yellowish brown and pale red micrite nodules in a pale yellowish 


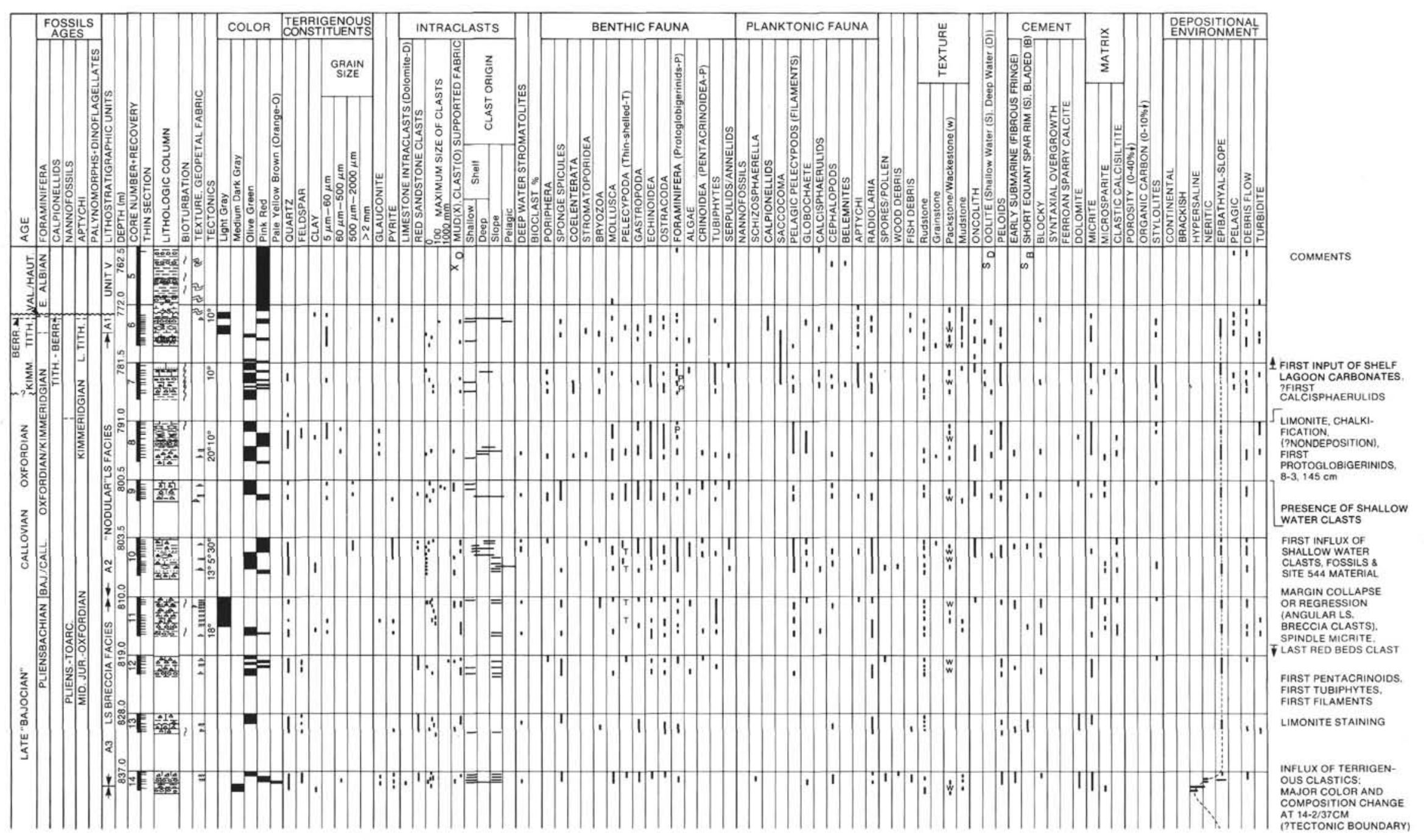




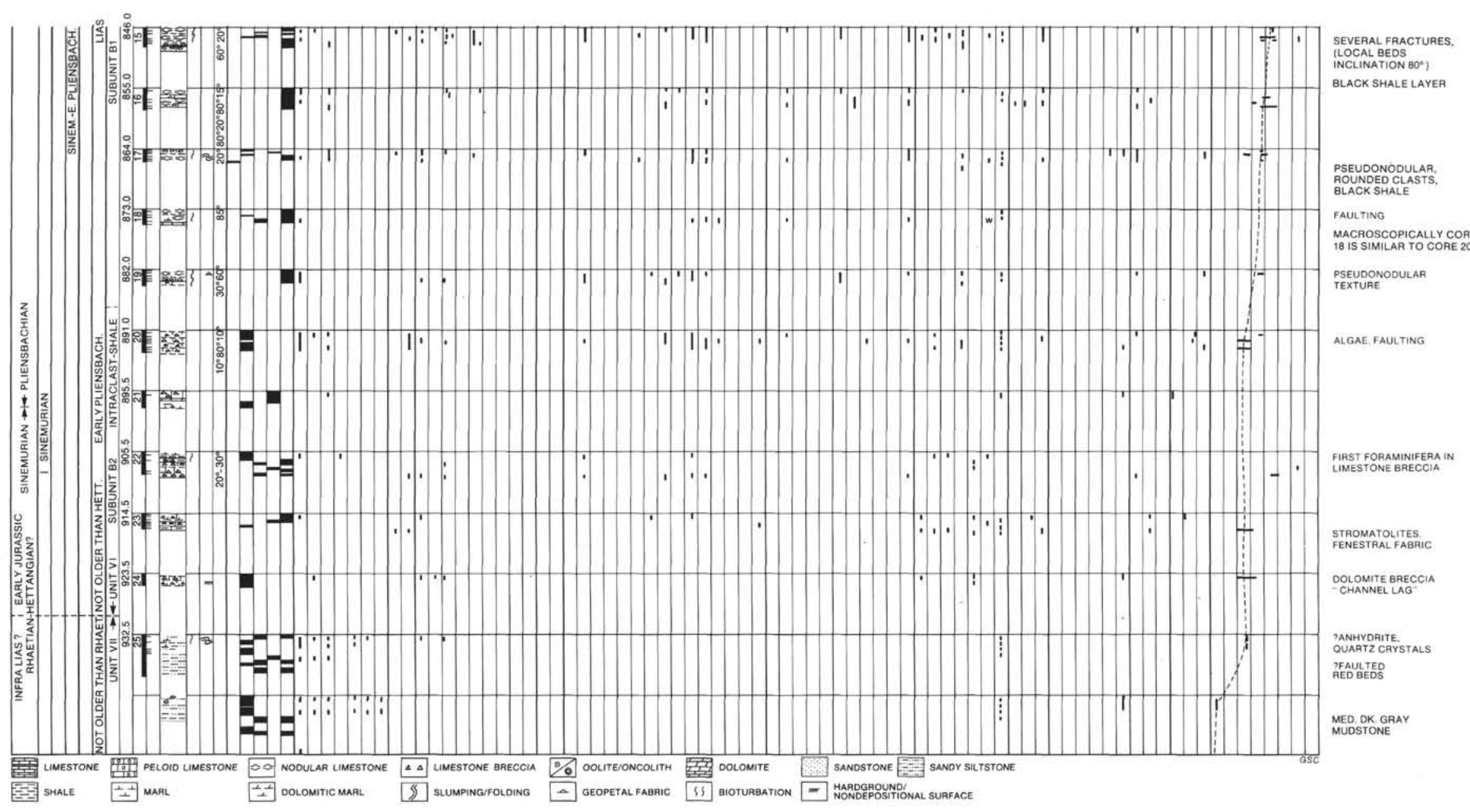

Figure 7. Geologic chart for limestone sequence in Hole 547B. Plot shows lithology, unit boundaries, ages, and interpreted depositional environment. Constituents and textural parameters derived from thin-section studies. 

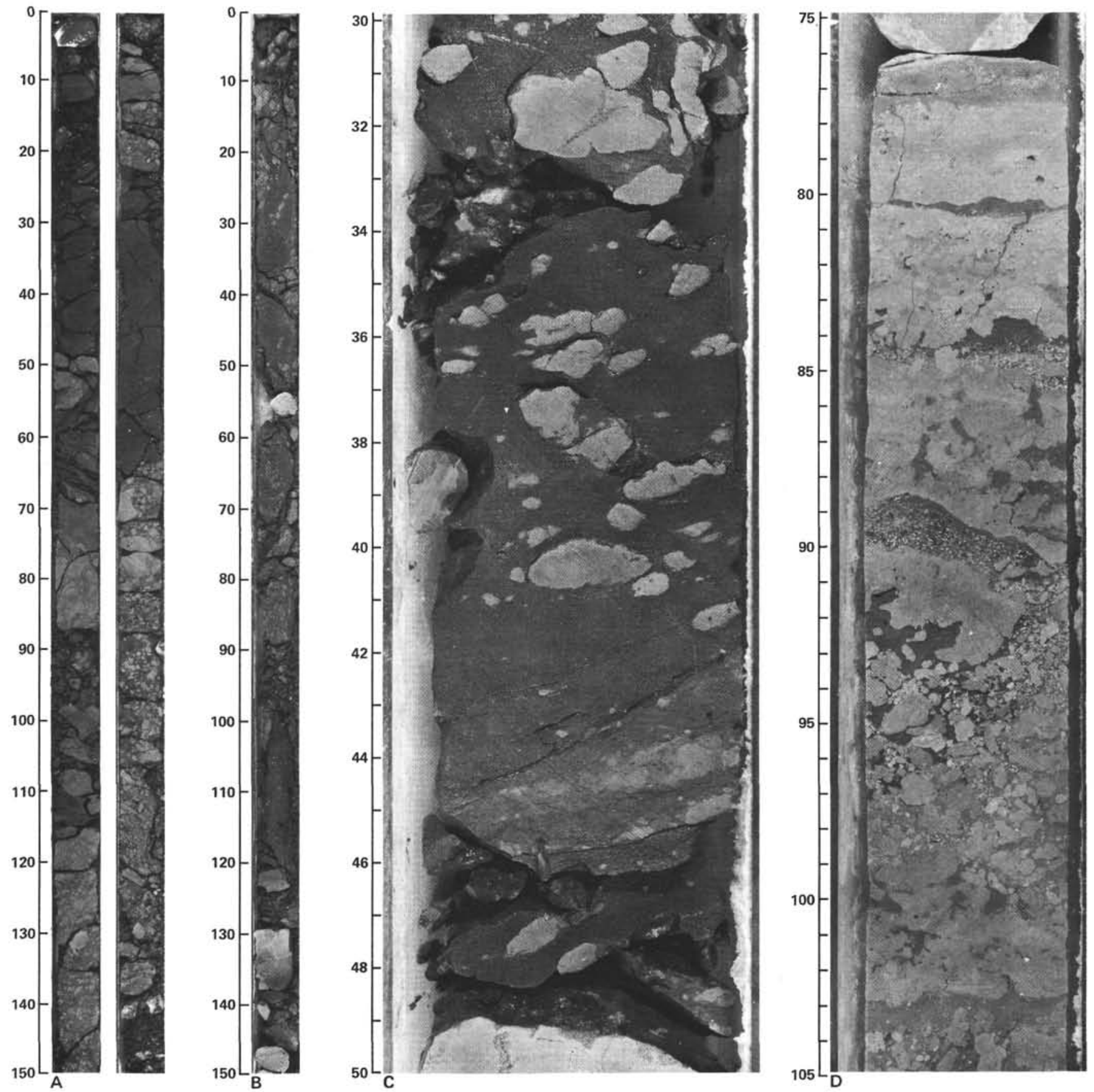

Figure 8. A. Olive black dolomitic mudstone and highly argillaceous micritic limestone which alternate with horizons of nodular and intraclast limestone (Subunit VIB2). Sections 547B-22-1 and 547B-22-2. B. Tectonic deformation of beds in Section 547B-18-1. Note locally vertical dip of the strata and possibly overturned beds near top of the core (Subunit VIB1). C. Nodules of pale red micrite reworked into moderately brown claystone, Sample 547B-15-1, 30-50 cm. D. Limestone debris flows separated by micritic crusts at 75 and $100 \mathrm{~cm}$. The "crust" layers were deposited at the top of each debris flow. Sample 547B-11-2, 75-105 cm.

brown calcareous claystone matrix with a few radiolarian-spiculitic micrite beds, $10-20 \mathrm{~cm}$ thick (Fig. 10A), and five horizons of grayish black, laminated, organicmatter-rich claystone, $0.5-30-\mathrm{cm}$ thick. Multiple, brief, nondepositional surfaces occur in some of the micritic beds. The limestone in the lower part of the subunit has a less well developed nodular texture. Locally the micrite was tectonically crushed, with the clast boundaries partially dissolved and bordered by stylolites which pro- duce incipient "nodular" texture. Higher up the sequence, the polymictic composition of the mostly matrix supported nodular limestones indicates that the nodules were reworked and gravitationally displaced (Fig. 8C). The majority of clasts and nodules are biomicrite with calcite-replaced casts of radiolarians, rare ostracodes, Globochaete, and poorly preserved foraminifers. Clasts of skeletal-peloid wackestones, with faunal remains of echinoids, pelecypods, and foraminifers be- 

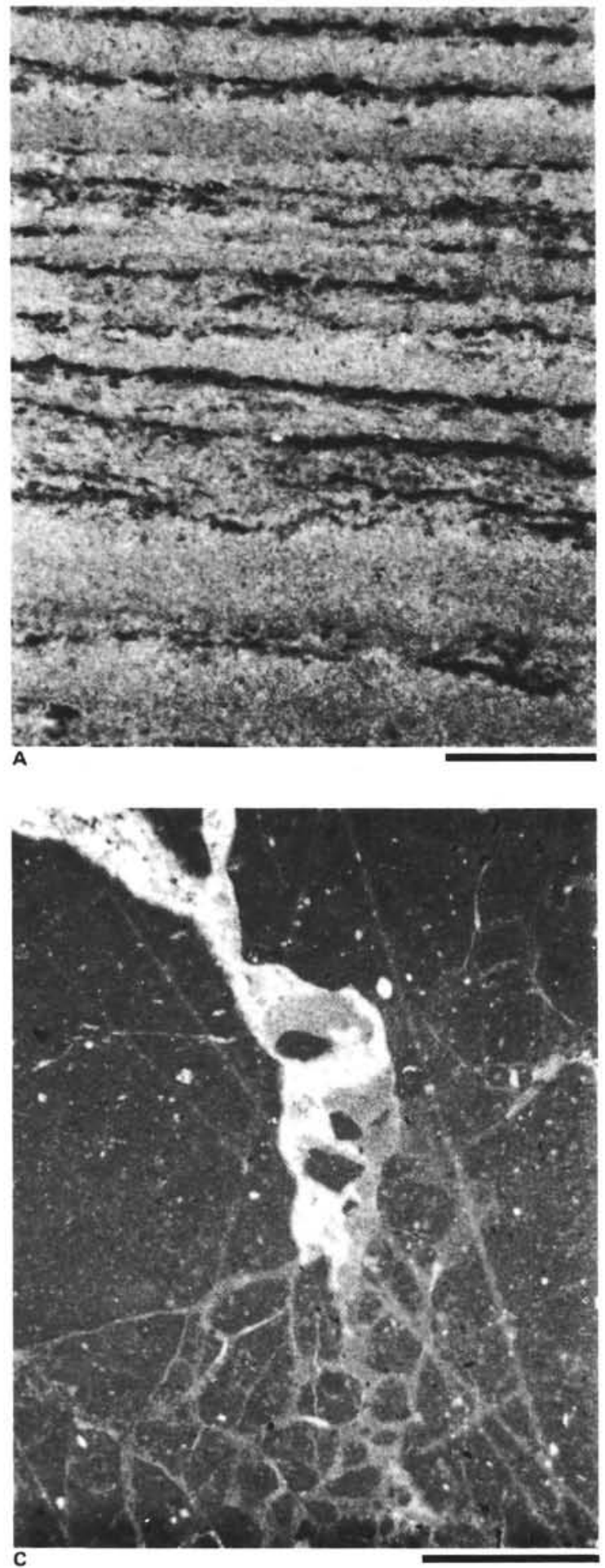
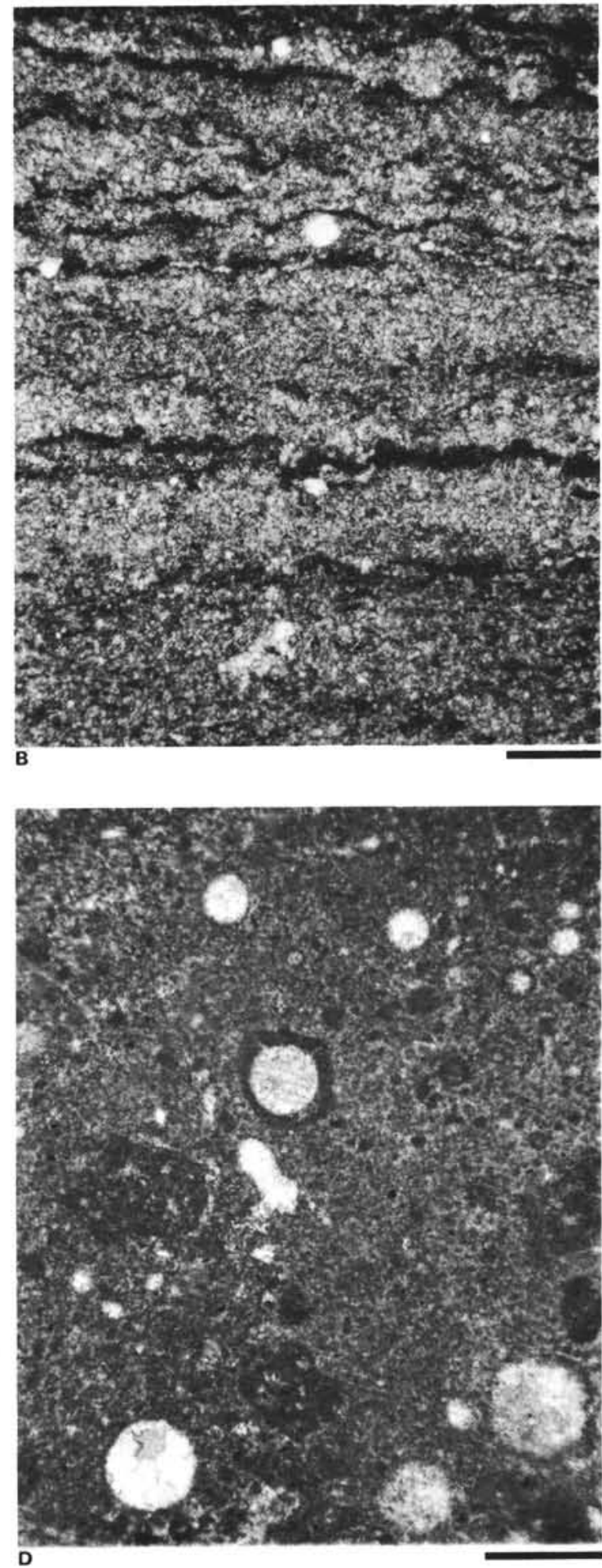

Figure 9. A. Laminated microcrystalline, intertidal dolomite, redeposited as a clast in the limestone breccia at the base of the Jurassic in Hole 547B (cf. Fig. 9B). The dark laminae show minute surface erosion and desiccation cracks. Sample 547B-23-2, 54-60 cm, thin section, crossed nicols, scale bar $1 \mathrm{~mm}$. B. Laminated intertidal, stromatolitic dolomite outcropping in the Essaouira Basin, NW of Ameskhoud, Morocco. Basal part of the Amsitten Formation (Lower Jurassic). Thin section, crossed nicols, scale bar $0.5 \mathrm{~mm}$. C. Biomicrite with silt-sized skeletal remains of ostracodes, primitive lagenids, and spicules. Limestone was fractured, with fractures healed by calcite. Sample 547B-23-1, $121 \mathrm{~cm}$, thin section, crossed nicols, scale bar $1 \mathrm{~mm}$. D. Sparry-calcite-replaced radiolarian test in a clast of radiolarian-spiculitic-peloid packstone from polymictic limestone breccia bed. Sample 547B-22-3, 15-21 cm, thin secton, crossed nicols, scale bar $25 \mu \mathrm{m}$. 

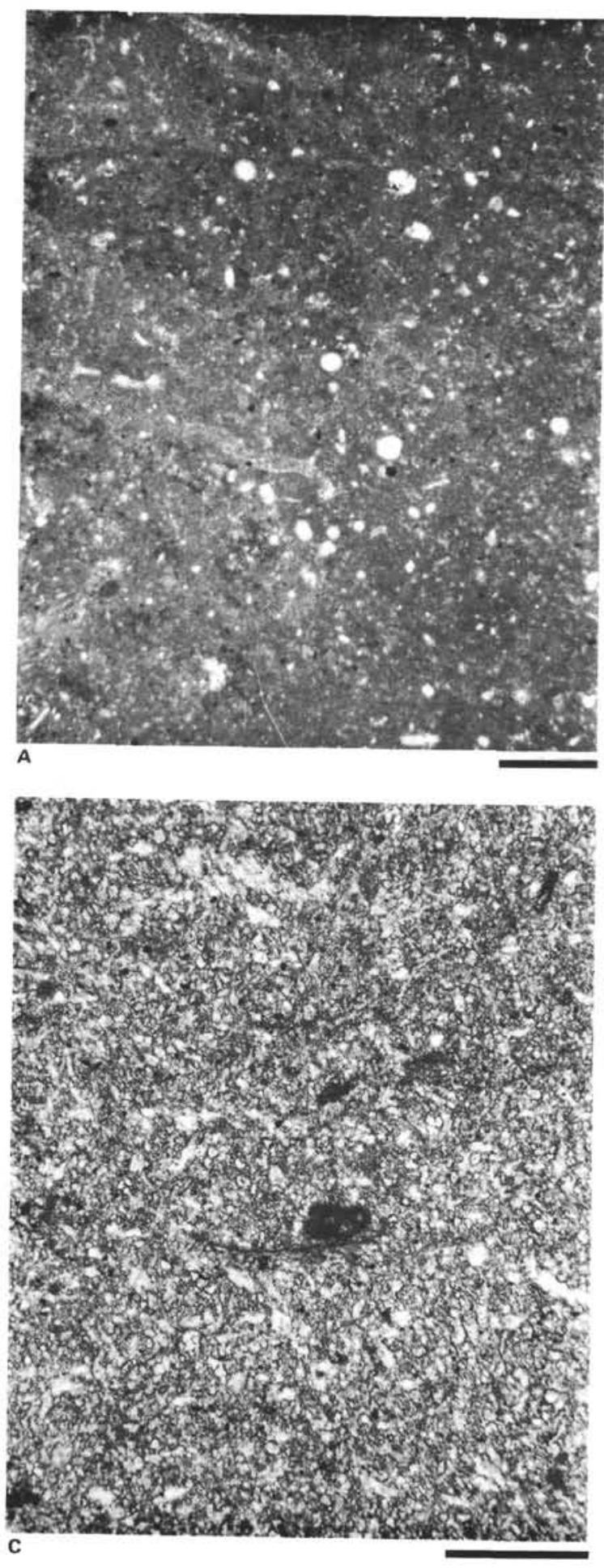
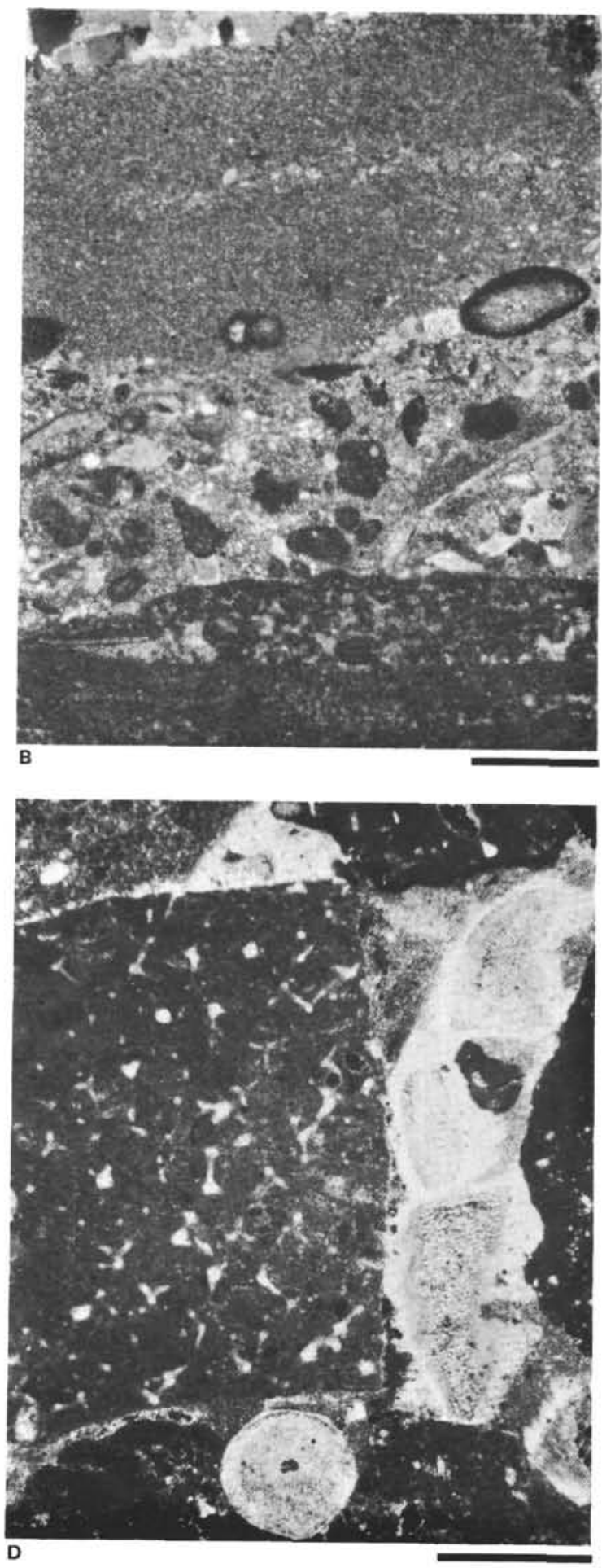

Figure 10. A. Bioturbated, silt-sized, peloid-skeletal packstone with calcite-replaced tests of radiolarians, sponge spicules, rare ostracode tests, and Globochaete. Dark specks are iron monosulfide and minute pyrite crystals. Sample 547B-15-1, $136 \mathrm{~cm}$, thin section, crossed nicols, scale bar $0.5 \mathrm{~mm}$. B. Limestone conglomerate with clast of sponges, radiolarian-peloid wackestone, and syntaxially overgrown fragments of crinoids. Note angular shape of sponge clast, which suggests that limestone was fragmented after lithification. Sample 547B-12-2, $100 \mathrm{~cm}$, thin section, plane light, scale bar $1 \mathrm{~mm}$. C. Unidentifiable silt-sized debris of limestone with test of ?textularid foraminifer. The limestone bed is interpreted as a grain flow. Sample 547B-11-3, $71 \mathrm{~cm}$, thin section, plane light, scale bar $0.5 \mathrm{~mm}$. D. Stromatolitic crust in the lower third of the microphotograph is overlain by sand-sized limestone debris which in turn is overlain by void-filling calcisiltite. The rest of the shelter cavity in this limestone breccia bed was infilled by sparry calcite cement. Sample 547B-10-1, $143 \mathrm{~cm}$, thin section, crossed nicols, scale bar $0.5 \mathrm{~mm}$. 
come more frequent near the top of the subunit. Clasts of unfossiliferous micrite and fine crystalline and laminated dolomite also occur in the polymictic breccias; this indicates mixing of shelf and slope carbonates. The matrix of the polymictic breccias is dark yellowish brown argillaceous micrite to calcareous claystone. Schizosphaerella is common in both the argillaceous matrix and clasts (Kälin and Bernoulli, this volume).

Study of the texture of nodular limestones indicates three main origins: (a) incipient, diagenetically formed nodules in pelagic carbonate, occasionally rotated and transported only a short distance; (b) fragmentation of lithified limestone; fragments are rounded by intense solution on clast contacts. The fragments which are bordered by stylolites are mainly in situ, or were transported only a short distance; (c) rounded clasts in matrix-supported polymictic breccia with clasts derived mainly from a pelagic (slope) source. The soft limestone clasts were rounded during transport and the rock attained the appearance of a nodular, matrix-supported limestone. The origin of nodular limestones is discussed in more detail by Steiger and Jansa (this volume).

The age of Subunit VIB1 is not well established, but foraminiferal studies suggest that it is latest Sinemurian to early Pliensbachian (Riegraf et al., this volume).

The lithologic boundary between Subunits VIB and VIA is sharp. The brecciated, dark gray mudstone with floating light gray limestone clasts of Subunit VIB1 is overlain by dolomitized, orange-colored micrite of Subunit VIA3 which in turn is overlain by limestone conglomerate with sandstone clasts and quartz-sandy laminae. We interpret the boundary between Subunits VIA and VIB as tectonic, but because only $30 \%$ of the core was recovered, we cannot exclude the possibility that brecciation is an artifact of drilling.

\section{Subunit VIA3 (547B-14-2, $37 \mathrm{~cm}$ to top of Core 11; 810-839 m sub-bottom)}

Subunit VIA3 is a distinct $29 \mathrm{~m}$ thick zone of mainly reddish brown and sandy limestone breccias and conglomerates. Limestone grain-flow beds several to tens of centimeters thick are intercalated within the upper part of Subunit VIA3 and occur particularly in Core 11. The clasts in the breccias and conglomerates vary from coarse-sand-sized to pebble-sized, with one boulder(?) $50 \mathrm{~cm}$ in diameter. The clasts are poorly sorted and mostly subangular. Some of the clasts are of second-cycle origin, with clasts composed of a finer-grained breccia of similar composition to that in which the clast is now enclosed. The original fabric of the breccia beds was open and clast supported, with voids now geopetally infilled by internal sediment that shows one or more stages of infiltration. Coarse, blocky, sparry calcite fills the remaining voids. The individual limestone breccia beds are capped by either bioturbated or laminated micrite separating individual depositional events (Fig. 8D). Thirty-two repetitive sequences, each starting with conglomerate or breccia at the base and capped by a micrite layer 2 to $5 \mathrm{~cm}$ thick, indicate successive debris-flow deposition.
The clasts of the breccias are pale red, grayish red, and light greenish gray in color, and are composed of radiolarian-spiculitic biomicrites, peloid packstones, and wackestones, skeletal wackestones, and packstones with faunal remains of echinoids, thick-walled mollusks, pentacrinoids, sponges, Tubiphytes and aptychi (Fig. 10B). Clasts of fine crystalline dolomite and reddish-colored dolospar also occur. Clasts of terrigenous origin, such as reddish sandstone, arkosic sandstone, siltstone, and argillaceous siltstone are frequent in some of the limestone breccia and conglomerate beds. Clasts of sandy limestone, laminated peloid packstone, and sponge-peloid packstone are rare.

The matrix of the limestone interclast beds is detrital calcisiltite, merged, silt-sized peloid packstone, or micrite; the last is locally neomorphically replaced by microsparite. Particularly in the lower half of the subunit, the matrix is occasionally terrigeneous, with up to $20 \%$ quartz sand with feldspars and traces of glauconite and muscovite. In the detrital calcisiltite matrix, some of the calcite grains are spindleshaped and may represent casts after aragonite. Rare fossils in the micritic matrix consist of debris of echinoids, mollusks, gastropods, and ammonites. Tubiphytes (which also appear in intraclasts) and filaments occur for the first time (Fig. 7). Radiolarian casts filled by sparry calcite and spicules are also present. Schizosphaerella has not been observed above Core 14.

The limestone debris-flow deposits, especially those in Core 11, show complex filling of the sheltered cavities. During several periods, the internal sediment infiltrated the cavities and internal lamination developed. The void-fill is composed of alternating laminae of micrite, calcisiltite, and silt-sized peloid packstone. In some of the breccia beds the internal sediment infilling was followed by deposition of an early submarine aragonitic cement, now replaced by cloudy, bladed, sparry calcite. Later, the remaining voids were filled by coarse, blocky, sparry calcite. Rare $\mathrm{Fe} / \mathrm{Mn}$ coatings on the surfaces of clasts and occasional borings and coating by stromatolites indicate that the surfaces of the uppermost clasts deposited by debris flows were exposed for a short time on the sea bottom before they were buried by either pelagic sediment or the next layer of gravity-displaced sediment.

Foraminiferal studies by Riegraf et al. (this volume) indicate that the core catcher of Core 11 contains a fauna of Pliensbachian age. The dominance of reworked and gravity-displaced sediment makes it probable that the foraminiferal assemblage in Core 11 was obtained from redeposited clasts. In the Tethyan region, pelagic pelecypods are Posidonia and/or Bositra which, in thin sections, have the appearance of filaments. The presence of such filaments in Subunit VIA3 suggests that the subunit is most probably Toarcian to Middle Jurassic. The age assignment is supported by the influx of terrigenous clastics in Subunit VIA3, which is characteristics of the Middle Jurassic around the North Atlantic margins (Jansa and Wade, 1975; Jansa and Wiedmann, 1982). 
The distinct, sharp lithological change from the debris-flow deposits to the overlying, dark, reddish brown nodular limestone marks the upper boundary of the subunit.

\section{Subunit VIA2 (Core 547B-10 to 547B-6-3, $140 \mathrm{~cm} ; 777.9-810 \mathrm{~m}$ sub-bottom)}

Reddish brown and/or light greenish gray nodular limestone (Fig. 11A) alternates with light gray beds of limestone breccia, limestone conglomerate, minor beds of skeletal micritic limestone, and greenish gray marl. Thin-section study of nodular limestone from the base of the subunit shows that the "nodules" are rounded to irregular in shape, and some are elongated and tearshaped. The nodules are composed of darker, denser biomicrite with calcite-replaced molds of radiolarians, ostracodes, Globochaete, filaments, and traces of mollusks. The matrix of the limestones is calcisiltite mixed with clay and fine quartz silt, all stained red by iron oxides. The quartz in the matrix is occasionally concentrated into wispy laminae. Fossil remains are much less frequent in the matrix than in the nodules, but traces of Globochaete, calcispherulids, foraminifers, annelids, and ammonite shell debris were observed. The shape and composition of the "nodules" indicate that they were displaced and that this nodular limestone is another type of mass-flow deposit where the carbonate was transported as a soft sediment. The rock texture is thus pseudonodular.

The pseudonodular limestone is overlain by a zone of multiple limestone breccias that form beds 2 to $4 \mathrm{~m}$ thick which are found from the base of Section 547B10-2 to the top of Section 547B-8-3. The breccias are separated from each other by a thin layer of micritic crust, similar to Subunit VIA3. Clasts in the breccias are subangular to subrounded, several $\mathrm{mm}$ to $4 \mathrm{~cm}$ in size and unsorted; the large clasts are floating in a matrix of fine, sand-sized limestone debris. The clasts in the limestone breccias and conglomerates of subunit VIA2 are smaller than those in Subunit VIA3.

The composition of the limestone intraclasts changes significantly near the base of Subunit VIA2 (Section 547B-10-2). Shallow-water skeletal carbonate debris is the major component of limestone intraclasts for the first time. Echinoids, gastropods, thick-walled mollusks, ammonites, thin pelecypod shells, and foraminifers are common in the coarse-grained skeletal wackestone intraclasts. Clasts with oncoliths, and coated grains which have pentacrinoids and filaments as a nucleus occur for the first time at this stratigraphic level. Pelagic oolites (similar to those in Site 544), Tubiphytes, rare aptychi, sponge, coral, stromatoporoid debris, and algal balls are other components of the intraclasts. The presence of pelagic oolites and oncoliths in the limestone intraclasts indicates input of sediment from the adjacent high capped with a carbonate platform, on which Site 544 was located. Intraclasts of radiolarian-spiculitic biomicrite, which was derived from the slope, continue to be present and are mixed with intraclasts derived from the carbonate shelf. Thus the composition of the clasts shows the multiple sources of the limestone debris, which was derived from the shelf, slope, and outer carbonate plateau.

Geopetal filling is very common in limestone breccia beds. The voids, which originated mainly as sheltered cavities under and between large clasts, were infilled in several stages by internal sediment and sparry calcite cement which left no original porosity. Stromatolitic laminae and micrite layers cap the individual debris-flow deposits, as in Subunit VIA3 (Fig. 10D).

The nodular limestone in the upper part of Subunit IVA2 (Core 8) differs from the pseudonodular limestone occurring at the base of the subunit by the indistinct boundaries between nodules and matrix in the former. Nodules are formed by biomicrite and skeletal wackestones containing filaments, small gastropods, mollusk debris, Globochaete, echinoid debris, and protoglobigerinids. The nodules are enclosed in a matrix that is of similar composition, but more argillaceous. These nodules are probably the result of differential lithification of carbonate sediment and are mostly in situ. However, the presence of filamentous coquina at the base of the nodular limestone (Fig. 12A) indicates that even here reworking and transport of carbonate particles were periodically intensive.

The part of the subunit above Core 8 is lithologically more variable than the underlying portion of Subunit VIA2. Beds of limestone conglomerate, intraclast breccia, argillaceous micrite, skeletal grainstone, bioturbated skeletal wackestone, skeletal-peloid wackestone, and mudstone are present, with fine-grained lithologies dominating the upper part of Subunit VIA2. Several trends in the changes of limestone composition are significant for age determination and subunit evaluation (Fig. 7):

1. Oncoliths and pelagic oolites are common in the intraclasts between Section 547B-10-2 and Section 547B-6-3;

2. Shallow-water oolites occur only above Core 8 , which indicates development of oolitic shoals near the paleoshelf edge at this time;

3. The presence of chalkified grains in Cores 8 and 7 bears upon the age of the subunit when compared to Site 545;

4. Rare fragments of corals, stromatoporoids, and sponges (calcareous and hexasponges) in intraclasts throughout Subunit VIA indicate favorable conditions for the evolution of coral bioherms near the paleoshelf;

5 . The occurrence of pelagic pelecypods (filaments) from the base of Core 10 to Section 547B-7-2 (Fig. 12A), protoglobigerinids (Section 547B-8-2 to Section 547B-7-3; Fig. 12B), and pelagic crinoids (Saccocoma; Section 547B-7-2 to base of Section 547B-6-3, Fig. 12C) all indicate a Late Jurassic age for Subunit VIA2.

Core 10 has been dated from foraminiferal studies as Bajocian-Callovian (Riegraf et al., this volume) which, together with the distribution of microfossils described above, suggests a Callovian to late Kimmeridgian/early Tithonian age for Subunit VIA2.

The boundary between Subunits VIA2 and VIA1 is placed at a sharp color change between the underlying, mainly reddish brown and greenish gray limestones and the overlying light gray to whitish limestones intercalat- 

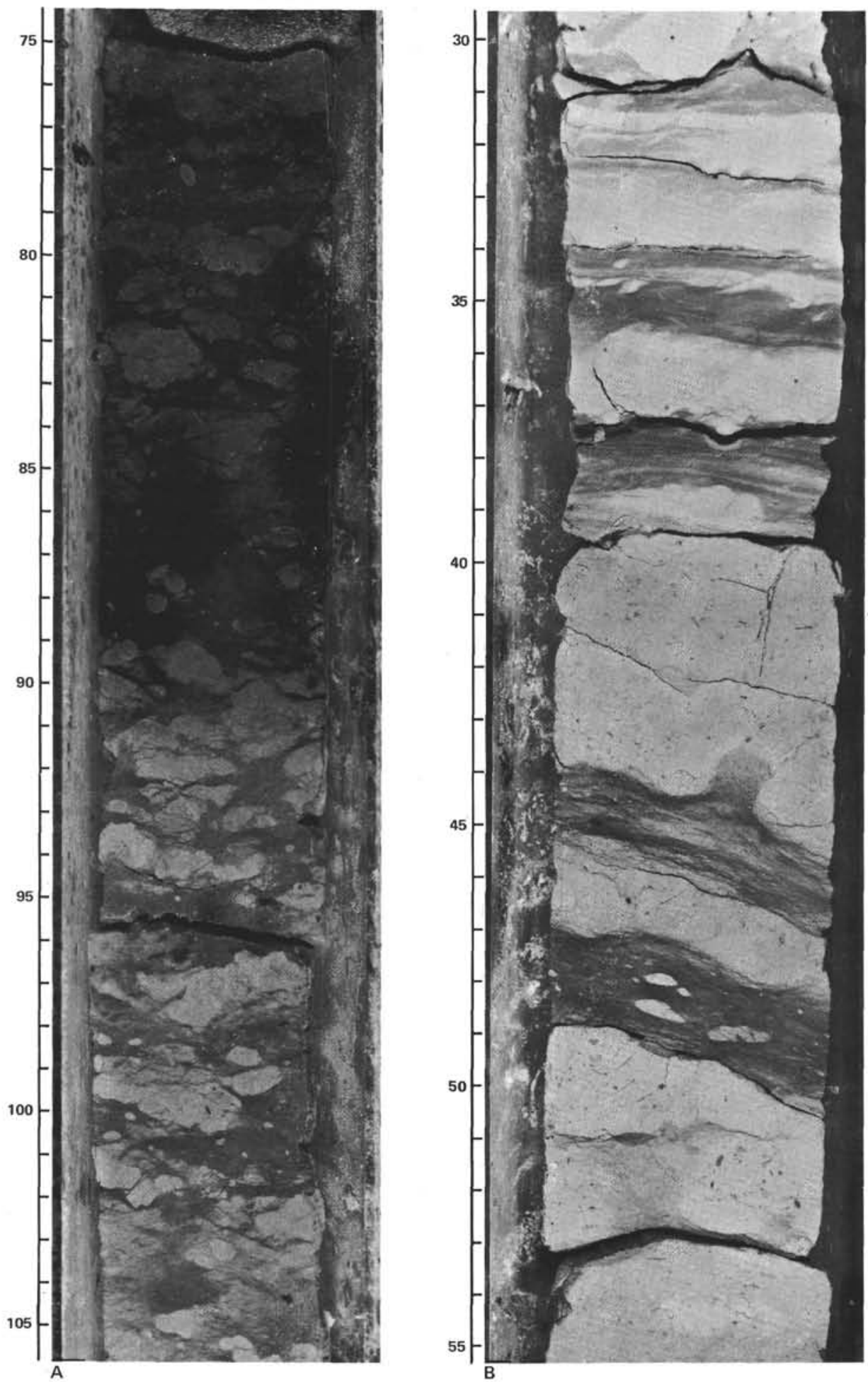

Figure 11. A. Nodular limestone (Subunit VIA2) which shows a distinct color boundary between reddish brown and light greenish gray limestone unaccompanied by lithologic change. The color change is late diagenetic or postdiagenetic in origin. Sample 547B-8-2, 75-105 cm. B. Light gray micritic limestone separated by thin layers of argillaceous matter which was concentrated by dissolution (Subunit VIA1). Note the dense accumulation of microstylolites visible in one of the layers. Sample $547 \mathrm{~B}-6-3,30-55 \mathrm{~cm}$. 

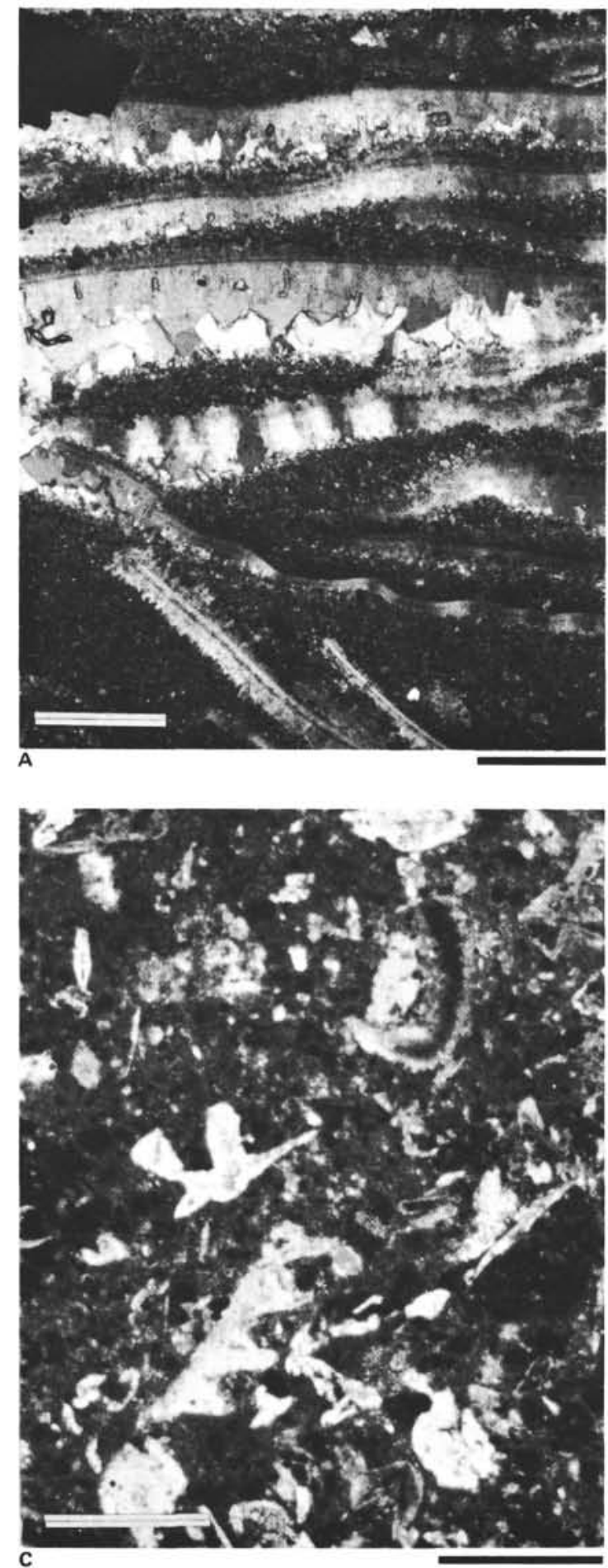
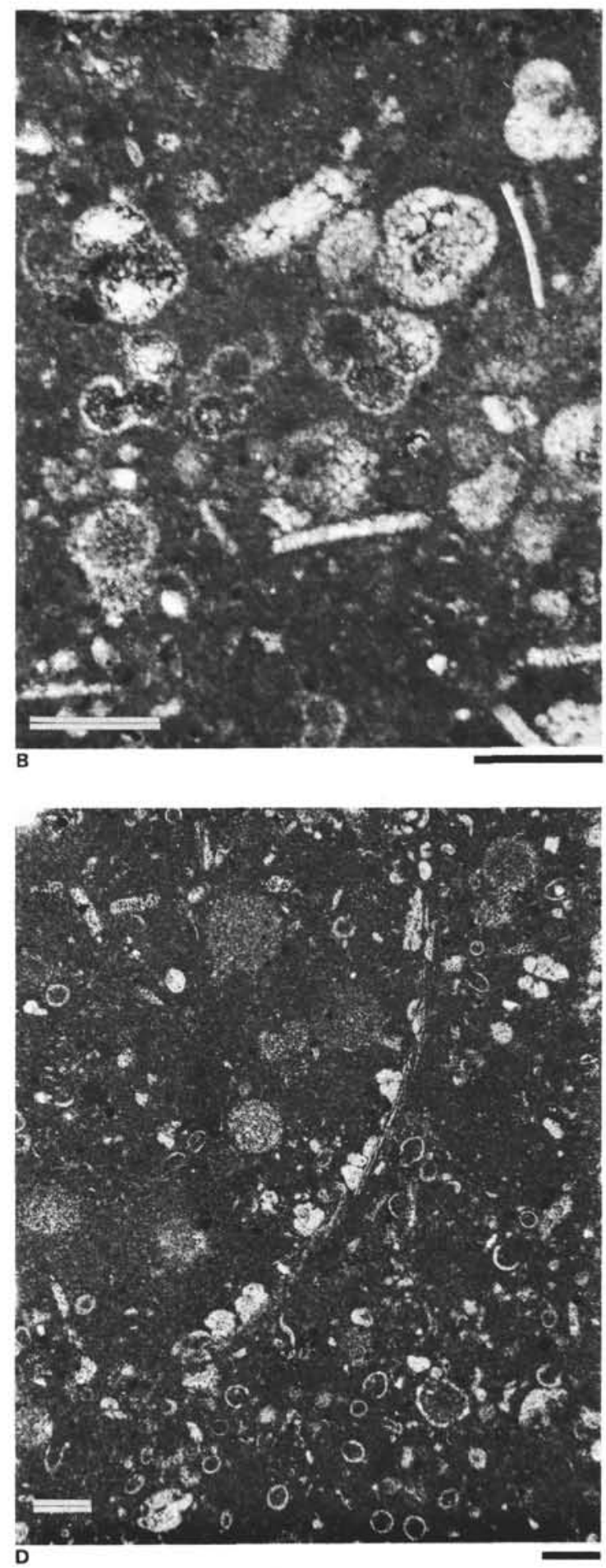

Figure 12. A. Coquina of thin pelagic pelecypod shells (filaments). Filaments are rimmed by bladed and blocky, sparry calcite rim. Calcisiltite infiltrated sheltered cavities and the rest of these cavities was filled by blocky, sparry calcite. Sample 547B-8-3, 30-55 $\mathrm{cm}$, thin section, crossed nicols, scale bar $0.25 \mathrm{~mm}$. B. Skeletal wackestone with sparry-calcite-replaced tests of protoglobigerinids, mollusk shell debris, and peloids deposited in micritic matrix; Sample 547B-7-2, $69 \mathrm{~cm}$, thin section, plane light, scale bar 0.25 $\mathrm{mm}$. C. Poorly sorted, skeletal peloid packstone with debris of pelagic crinoids (Saccocoma), aptychi, mollusk shells, and peloids; Sample 547B-6, CC, thin section, crossed nicols, scale bar $1 \mathrm{~mm}$. D. Skeletal wackesone with tests of calpionellids, Globochaeta alpina, and molds after radiolarians which were filled by microsparite. Sample 547B-6-2, $142 \mathrm{~cm}$, thin section, plane light, scale bar $0.1 \mathrm{~mm}$. 
ed with marly beds. Such as distinct color change is stratigraphically significant for the Late Jurassic of the central North Atlantic basins (Jansa, Gardner, et al., 1979; Jansa, Enos, et al., 1979).

\section{Subunit VIA1 (547B-6-3, $140 \mathrm{~cm}$ to $547 \mathrm{~B}-6-1$, $107 \mathrm{~cm} ; 773-777.9 \mathrm{~m}$ sub-bottom)}

Subunit VIA1 is very thin and is represented by light gray micrite limestone separated by stylolitic layers of marl (Fig. 11B), mud-supported polymitic breccia with clasts up to $15 \mathrm{~cm}$ in diameter, and by marly biomicrite alternating with 20 -cm-thick beds of greenish gray, highly bioturbated claystone, with Planolites and Chondrites trace fossils.

Study of thin sections show that the biomicrites and fine, silt-sized skeletal wackestones that dominate this subunit consist of micrite, debris of aptychi, mollusks, echinoderms, Globochaete, foraminifers and ostracodes, and calcite-replaced molds of radiolarians. Calpionellids are common from the base of the subunit to 547B6-2, $13 \mathrm{~cm}$ (Fig. 12D), but are missing above this stratigraphic level, where Nannoconus becomes common.

The intraclast breccia beds have a polymictic composition with clasts composed of calpionellid-radiolarian wackestone, peloid and peloid-skeletal wackestone, and superficial oolite-intraclast packstone, which are mixed with fragments of sponges, algae-encrusted grains, and Tubiphytes. The composition of the clasts indicates that mixing of the shelf- and slope-derived detritus continued into the Early Cretaceous. The occurrence of clasts with calpionellids provides evidence that some of the clasts are almost contemporaneous with the deposition.

Voids, filled geopetally by internal sediment, with walls rimmed by bladed, sparry calcite and the remaining space infilled by blocky, sparry calcite, are common. Clasts with reverse-oriented geopetal filling document early cementation of some of the limestones before they were incorporated into the debris flows.

The upper boundary of Subunit VIA1 has been placed at the lowest occurrence of the olive gray, nannofossilbearing Albian claystone, which constitutes the base of the overlying Unit V.

The age of Subunit VIA1, as determined from the occurrence of calpionellids (Azéma and Jaffrezo, this volume), aptychi (Renz, this volume), nannofossils, and foraminifers (site chapter, Riegraf et al., Wiegand, all this volume), is late Tithonian to Valanginian or midHauterivian. The limestones of Unit VI are separated by an unconformity from the overlying Albian mudstones (Unit V).

\section{Depositional Environment}

Faulting has affected the base of the Jurassic section at Site 547 and makes discussion of the depositional history of this part of the stratigraphic column speculative. The same sandy shales which underlie the base of the Jurassic limestone sequence are also intercalated within the Lower Jurassic limestone sequence and this may indicate that not much of the basal sequence is missing through faulting. The dominance of clay-size material deposited during the late Triassic, the lack of any fauna, and the presence of salt-marsh-derived spores, anhydrite nodules, and (?)root casts point to low relief and deposition in a playa-type or lake environment. The presence of minor evaporitic minerals and the dominant red color of the sediments suggest high evaporation and a hot climate.

The change from red beds to dark gray mudstones near the Triassic/Jurassic boundary can be explained by (a) major climatic change from arid to more humid as the sea invaded the region, which would cause increased transport of organic matter into the depositional basin; (b) lake deposition; or (c) rapid deposition in a prodelta environment. The lack of any fauna in the dark gray mudstone may support the last interpretation: rapid building of a prodelta into a "lake" formed in a graben, similar to the present rift lakes of the Afar region (Taieb, 1976) or to Tertiary half-grabens of the North China Platform (Quiuyuan and Wenxue, in press).

The lack of in situ shallow carbonates at the base of the Jurassic sequence is the result of rapid transgression of seawater into fault-bounded basins, the floors of which had already subsided below global sea level. The presence of algal stromatolites and intratidal dolomites in clasts of the limestone breccia beds at the base of the Jurassic sequence demonstrates that shallow-water carbonates were deposited in a photic zone at the basin margin. Incorporation of these shallow-water clasts into gravity-displaced beds requires steep fault escarpments, and demonstrates that transgression occurred into a tectonically differentiated, block-faulted region. The lack of coarse clastics in the underlying Triassic beds suggests low-lying terrain, and thus the slope has to be tectonic in origin, with faults rejuvenated during the Early Jurassic.

As a result of rapid subsidence and transgression, hemipelagic carbonates were deposited on the slope of the basin and from time to time were incorporated into debris flows and deposited at the toe of the slope. The frequent occurrence of gravity-displaced beds is an indication of tectonic instability and synsedimentary faulting in this region.

Fossils are completely lacking in the matrix of the limestone breccia beds, suggesting either that the floor of the basin was unfavorable to life, or that bottom waters were undersaturated in carbonate and the CCD level was very shallow at this time. The occasional occurrence of organic-carbon-rich layers in the Lower Jurassic deposits at Site 547 could be the result of local euxinic conditions (the shales are not bioturbated) that developed in response to restricted bottom-current circulation. The restriction could have been caused by active faulting in the area or by the emplacement of large volumes of debris which would form temporary barriers to deep-water circulation. The generally dark color of the Lower Jurassic sediments at Site 547 indicates either poor circulation of bottom waters in this part of the early Atlantic or higher input or organic matter into the basin than during the Late Jurassic. Geochemical study revealed that the organic matter intercalated within the Lower Jurassic sediments was mainly terrigenous. The organic matter debris was partly oxidized during transport, and most of the $C_{\text {org }}$ concentrations are below $1 \%$ 
(site chapter). The increased bioturbation in the upper part of the Lower Jurassic (Subunit VIB2) suggests that increased oxygenation of bottom waters allowed colonization by benthic organisms.

The prominent change from dark gray to reddish brown and greenish sediments during the Middle Jurassic is explained by an increased oxygen content in bottom waters, magnified by a decreased sedimentation rate. The color change does not need to be strictly due to a change in paleocirculation in the central North Atlantic Basin; it could reflect many other geologic processes such as climatic change, eustatic sea level change, or tectonism. The increased size of intraclasts, the clastsupported texture of the breccia beds, and the coarse terrigenous detritus in the Middle Jurassic (Subunit VIA3) are the result of regression. At this time, carbonate deposition expanded to the bottom of the basin as the CCD deepened. Continued deposition of limestone breccia at Site 547 during the Middle Jurassic indicates the continuing presence of a steep slope at the margin. Except for the terrigenous component derived from the adjacent basement high and in part from the Mazagan Plateau area, most of the limestone intraclasts were derived from the slope, with only minor contribution from the deeper, outer shelf.

A major change in the composition of interclasts occurs near the base of the Upper Jurassic Subunit VIA2, where shallow-water, high-energy carbonates and bioherm-derived debris, plus debris originating at the offshore high (Site 544), began to dominate over slope-derived intraclasts. Such a change indicates that the Early to Middle Jurassic carbonate ramp which dominated the Mazagan margin began to evolve into a carbonate platform on which carbonate shoals developed near the paleoshelf edge.

The progressive decrease in the frequency of limestone debris flows and the size of clasts and the increase in fine-grained carbonates in the uppermost Jurassic suggest either that the inclination of the slope was decreasing or that carbonate deposition could not keep pace with subsidence. Deepening of the margin (drowning of the platform), as at Site 547 , is contradictory to the evidence from Site 545, which indicates a period of regression during the Kimmeridgian similar to that suggested for the Essaouira Basin by Adams (1979). The most likely explanation of this phenomenon is that the margin was block-faulted and that individual tectonic blocks were undergoing different evolution.

The unconformable contact between the top of the Lower Cretaceous carbonates and the overlying Albian mudstones can best be explained as being due to nondeposition and submarine erosion (as in the upper slope of the Mazagan Plateau at Site 545), associated with the drowning of the outer carbonate platform of the Mazagan Plateau during the late Early Cretaceous.

\section{Age}

The biostratigraphic subdivision of the Early Cretaceous to Jurassic limestone sequence at Site 547 is difficult because age-diagnostic fossils are generally absent and redeposited sediments predominate. Because lime- stone intraclasts are abundant, it is uncertain which of the age dates are from the clasts and which are from the matrix (the latter giving true age and the former the age of the reworked material). The ages of the subunits given in Figure 7 were determined by combining available biostratigraphic data with lithologic correlation to other Leg 79 sites and to the Jurassic in the central North Atlantic Basin and coastal basin of Morocco.

According to palynology and the comparison with onshore Morocco, the red beds of Unit VII are probably of late Triassic to Early Jurassic age. In particular, the dark gray mudstone at the top of Subunit VII is no older than Rhaetian but could be as young as Early Jurassic (Fenton, this volume).

The base of the carbonate sequence at Site 547, from foraminiferal investigations, is Hettanginian-Sinemurian (Riegraf et al., this volume, Fig. 7). If the top of Unit VII is as young as early Jurassic, then the base of the carbonates can be placed in the Sinemurian, comparable to the development of the Mesozoic at other continental margins around the North Atlantic (Jansa and Wade, 1975; Jansa and Wiedmann, 1982). The uppermost part of Subunit VIB2 is early Pliensbachian (Cores 21 and 20), from foraminiferal evidence (Riegraf et al., this volume). The Pliensbachian age for Core 15 is suggested from nannofossil studies (Wiegand, this volume). The Pliensbachian age for Core 11 (Riegraf et al., this volume) is not in agreement with the lithologic evolution of the Northwest African margin, and probably results from dating of intraclasts.

Influx of terrigenous sediments into the basin is typical for the Middle Jurassic around the North Atlantic, as already discussed for Site 545 . We suggest from this evidence that Subunit VIA3 is approximately BajocianBathonian in age.

The age of the overlying Subunit VIA2 is better constrained by microfossils, such as protoglobigerinids, filaments, Saccocoma, and aptychi (Fig. 12A-C). Such an association is characteristic for the Late Jurassic in the central North Atlantic (Jansa, Gardner, et al., 1979) as well as in the Mediterranean (Bernoulli, 1972). The Late Jurassic age of Subunit VIA2 is supported by foraminiferal evidence (Riegraf et al, this volume) and by aptychi (Renz, this volume). Thus we conclude that Subunit VIA2 is (?)Callovian to early Tithonian in age.

The age of Subunit VIA1 is well constrained by the presence of calpionellids (Azéma and Jaffrezo, this volume) (Fig. 12D) and nannofossils (Wiegand, this volume) to the late Tithonian to Valanginian-Hauterivian.

The calculated sedimentation rates, according to this stratigraphic framework, show that deposition rates (not compensated for compaction) rapidly decreased from 6 $\mathrm{m} / \mathrm{m} . \mathrm{y}$. during the Early Jurassic to $1.5 \mathrm{~m} / \mathrm{m}$.y. during the Middle and Late Jurassic.

\section{Site 544}

Site 544 was located about $5 \mathrm{~km}$ westward of Site 547 in a water depth of $3607 \mathrm{~m}$, on the northwestern edge of a basement high plunging to the northwest from the Mazagan Plateau (Fig. 2). Multichannel seismic profiles across this structural high indicate that it represents an 
uplifted basement block, and fragments of granitic rocks were dredged from its flank (Wissmann and von Rad, 1979).

\section{Stratigraphic Resumé}

The rocks encountered at Site 544 are divided into five units. Units I and II consist of $103.8 \mathrm{~m}$ of pale yellowish brown and grayish orange pink, clayey, foraminiferal oozes and chalks deposited in a pelagic environment above the CCD. The oozes and chalks were dated by foraminifers and nannofossils as early Pleistocene to early Miocene. Unit II unconformably overlies the 34.5 $\mathrm{m}$ thick, reddish brown, skeletal limestones of Unit III. The age of the limestones is poorly established as Middle to Late Jurassic. The Jurassic limestones are underlain by $45 \mathrm{~m}$ of a grayish red, sandy mudstone and muddy sandstone (Unit IV), with coarse clasts of weathered gneiss and rare clasts of recrystallized, peloid grainstone. Most of the terrigenous grains are angular. Unit IV is interpreted as a colluvium-alluvium blanket cover overlying metamorphic basement. The age of Unit IV is unknown; however, the lithology is similar to the Triassic cropping out ashore in Morocco. The red beds sit on a pinkish gray, biotite-bearing, granitic gneiss (Unit V) of which $51 \mathrm{~m}$ were penetrated. The age of the gneiss provided by $\mathrm{K} / \mathrm{Ar}$ dating is $315-455$ m.y. (Kreuzer, this volume).

\section{Limestones of Unit III}

A detailed lithologic description of this unit is provided in the Site 544 site chapter, and results of petrographic study are discussed by Steiger and Jansa (this volume). As the results from additional detailed studies of the carbonates (Fig. 13) do not differ significantly from those reports, we summarize here only some of the features most pertinent to environmental discussion.

Limestones in Unit III (544A-12, CC to 544A-17-1, $23 \mathrm{~cm} ; 103.8-139.2 \mathrm{~m}$ ) are mainly reddish brown with pale yellowish brown and yellowish gray mottling. The uppermost several centimeters of the unit show more yellow color, which is caused by limonitization of the grains, suggesting a period of slow deposition or nondeposition near the top of the sequence. However, the uppermost surface of the limestone of Unit III has a fresh appearance without any $\mathrm{Fe} / \mathrm{Mn}$ coating.

Compositionally, Unit III is a coarse-grained oncolith-skeletal wackestone with minor grainstones and packstones, with little variation in composition in the vertical profile (Figs. 13, 14). In general, limestones near the base of the unit are coarser-grained, with more oncoliths and oolites than skeletal debris (Fig. 15A). Skeletal grains dominate over oncoliths near the top of the unit, where a micritic matrix increases and incipient hardgrounds are more frequent (Fig. 15D). Coated grains and oncoliths are a characteristic feature of the limestones (Fig. 15A). The coated grains usually contain filament as a nucleus, coated by multiple micrite laminae (Steiger and Jansa, this volume; Fig. 15B).

The skeletal debris which is mixed with oncoliths and pelagic oolites (as defined by Jenkyns, 1972) are of two different origins. The first is a shelf benthic assemblage of skeletal remains of gastropods, mollusks, echinoids
(Fig. 15B), pentacrinoids, serpulids, bryozoans, ostracodes, foraminifers, rare corals, and hexasponges. The second assemblage is represented by pelagic pelecypods (filaments), ammonites, Globochaete, traces of protoglobigerinids, saccocomids, and Schizosphaerella. Pelagic elements are mixed with the shelf assemblages. Additional limestone constituents include intraclasts of micrite, skeletal debris coated by micrite, fragments of skeletal packstones and wackestone, and cyanobacterial crust fragments. Only traces of silt-sized quartz are present in the micritic matrix of the packstones and wackestones. Grainstones are cemented by dirty, isopachous, bladed, sparry calcite. They have a patchy distribution, and some probably originated through bioturbation.

Another characteristic feature of the limestones is the presence of cyanobacterial crusts (Steiger and Jansa, this volume). This lithofacies is an irregularly laminated bindstone with dark-colored micrite or silt-sized, peloid, packstone laminae which envelop and bind finegrained, skeletal particles and oncoliths. The bindstone also forms the roof of the internal cavities which are geopetally filled by micrite and blocky, sparry calcite (Fig. 15C). The cavities form galleries or are scattered and laterally grade into grainstone pipes, indicating they are the result of bioturbation. Deep-water stromatolites are rare and have an irregularly digitated form and clotted fabric.

Hardgrounds, which increase in frequency toward the top of Unit III, show a complex history (see site chapter; Fig. 13). The surfaces are bored and encrusted by sessile organisms. They have an irregular knobby shape and some show thin films of $\mathrm{Fe} / \mathrm{Mn}$ coating (Fig. 15D). The lateral discontinuity of such surfaces and their very thin nature (never more than several $\mathrm{mm}$ thick) suggest they represent incipient hardgrounds.

\section{Depositional Environment}

Sediment composition and associated fauna provide good evidence on depositional conditions at Site 544 during the Middle and (?)Late Jurassic. The general wackestone/packstone lithology and the abundance of pelagic oolites and algal oncoliths indicate deposition in a low- to moderate-energy photic zone. The presence of shelf biota further indicates that deposition occurred in a moderately deep shelf, below wave base, but shallow enough that the bottom could have been occasionally stirred by currents during large storms. The evidence for storm deposition is the occurrence of coarse, sand-sized and pebble-sized intraclasts. The intraclasts, which frequently occur near the hardgrounds, provide additional evidence of early consolidation or early cementation of bottom deposits. Cementation was probably patchy and led to the development of discontinuous crusts which were from time to time broken by wave action and redeposited by currents. The increase in frequency of hardgrounds toward the top of the unit suggests a decrease of depositional rate, perhaps reflecting progressive deepening of the depositional environment at this stage.

Textural characteristics of the carbonate deposits at Site 544 are similar to the Quaternary of the Yucatan Shelf (Logan et al., 1969). The Progresso blanket of the 


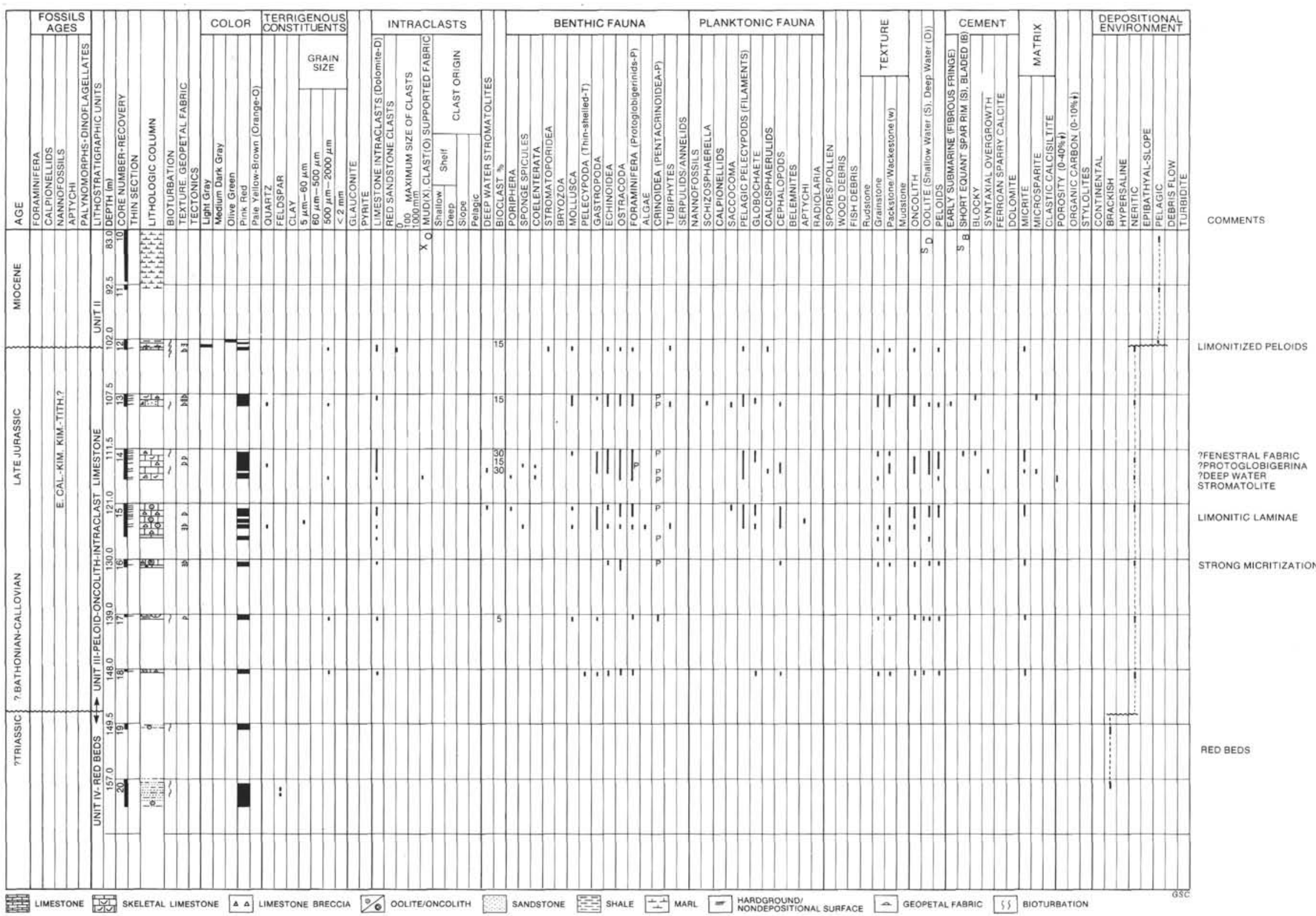
derived from thin-section studies. 

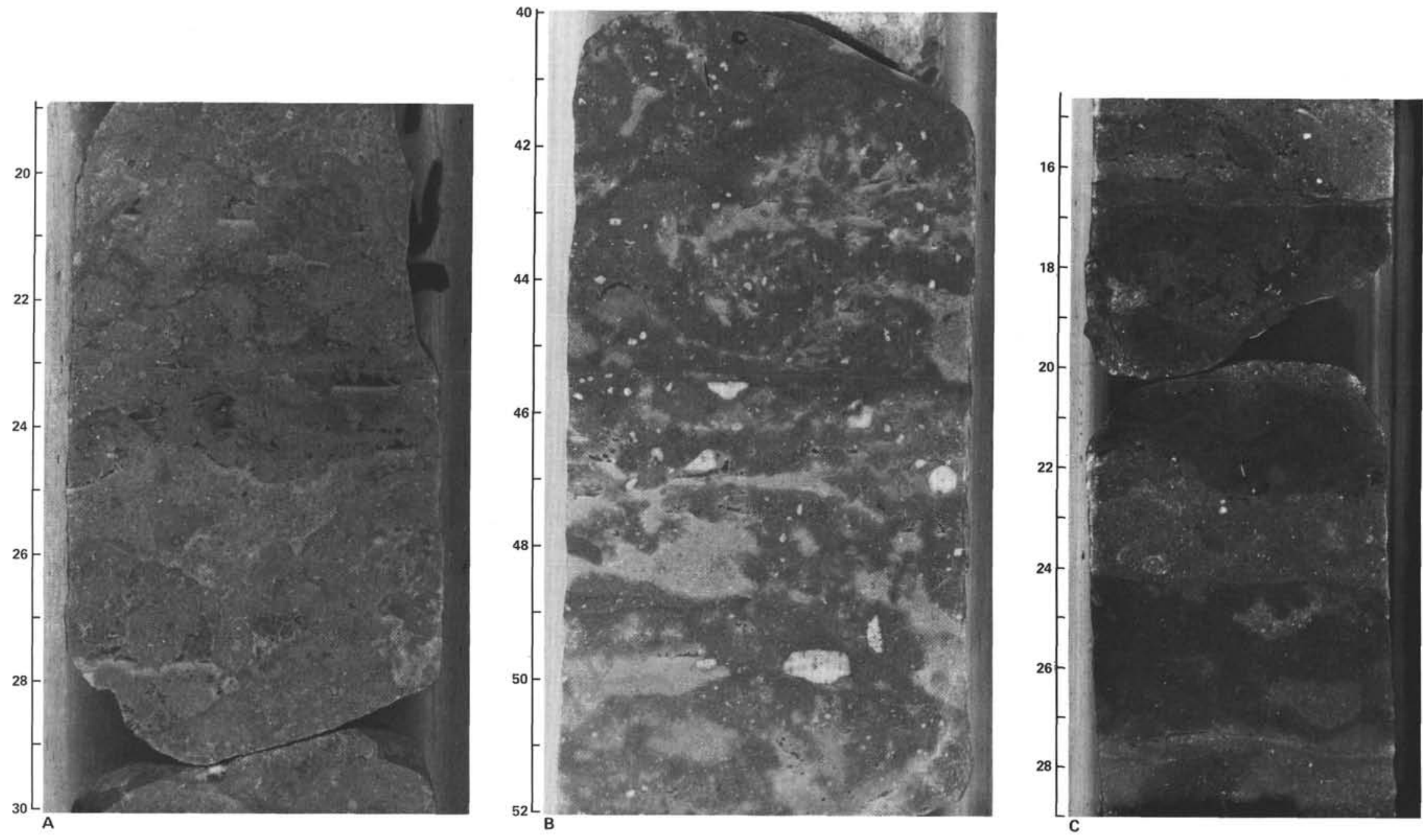

Figure 14. A. Intraclast-oncoidal packstone with geopetal fabric; cavities filled by micrite and sparry calcite cement. Note weakly visible nondepositional surfaces at 20 and $26 \mathrm{~cm}$. Sample $544 \mathrm{~A}-15-3,19-30 \mathrm{~cm}$. B. Reddish brown and gray mottled skeletal packstone enclosing debris of pentacrinoids. Mottling could be the result of bioturbation. Sample $544 \mathrm{~A}-13-2,40-50 \mathrm{~cm}$. C. Hardground, with surface truncated, bored, and overlain by a thin irregular sequence of multiple nondepositional surfaces, which are coated by a thin film of Fe/Mn. Geopetal fabric is well developed in the sequence. Sample 544A-13-1, 14-29 cm. 

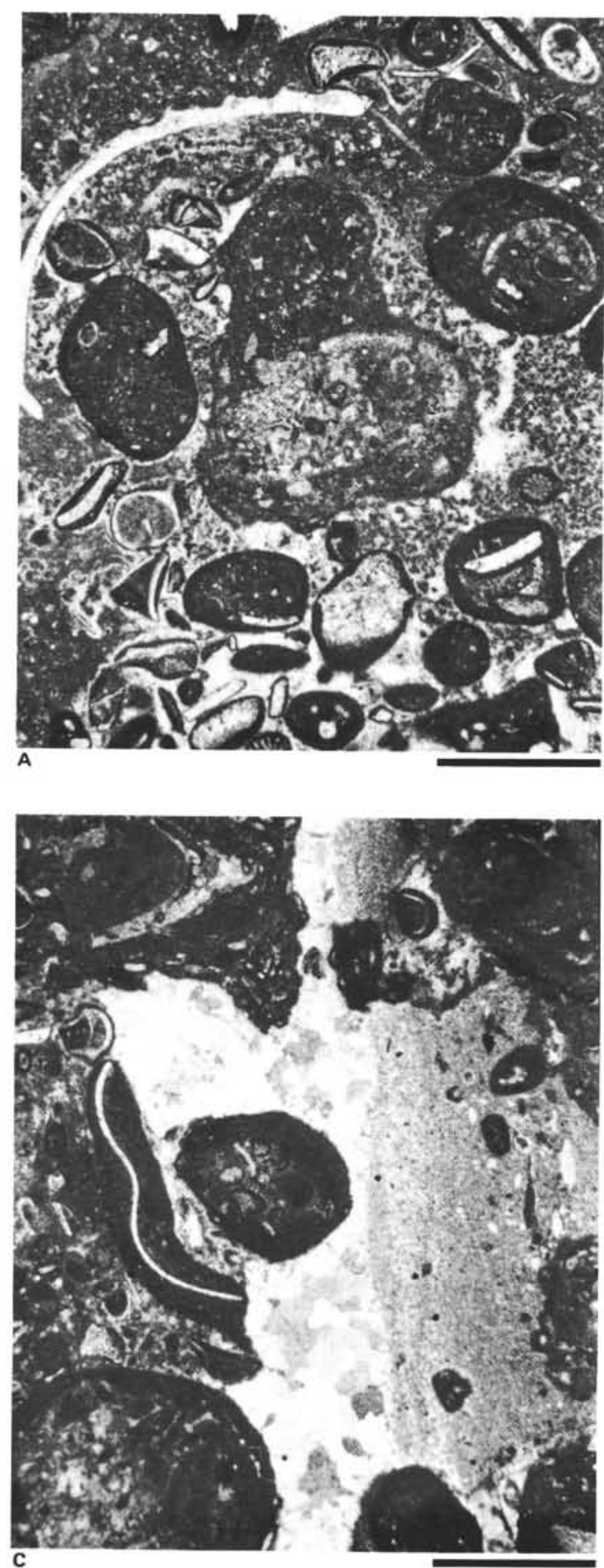
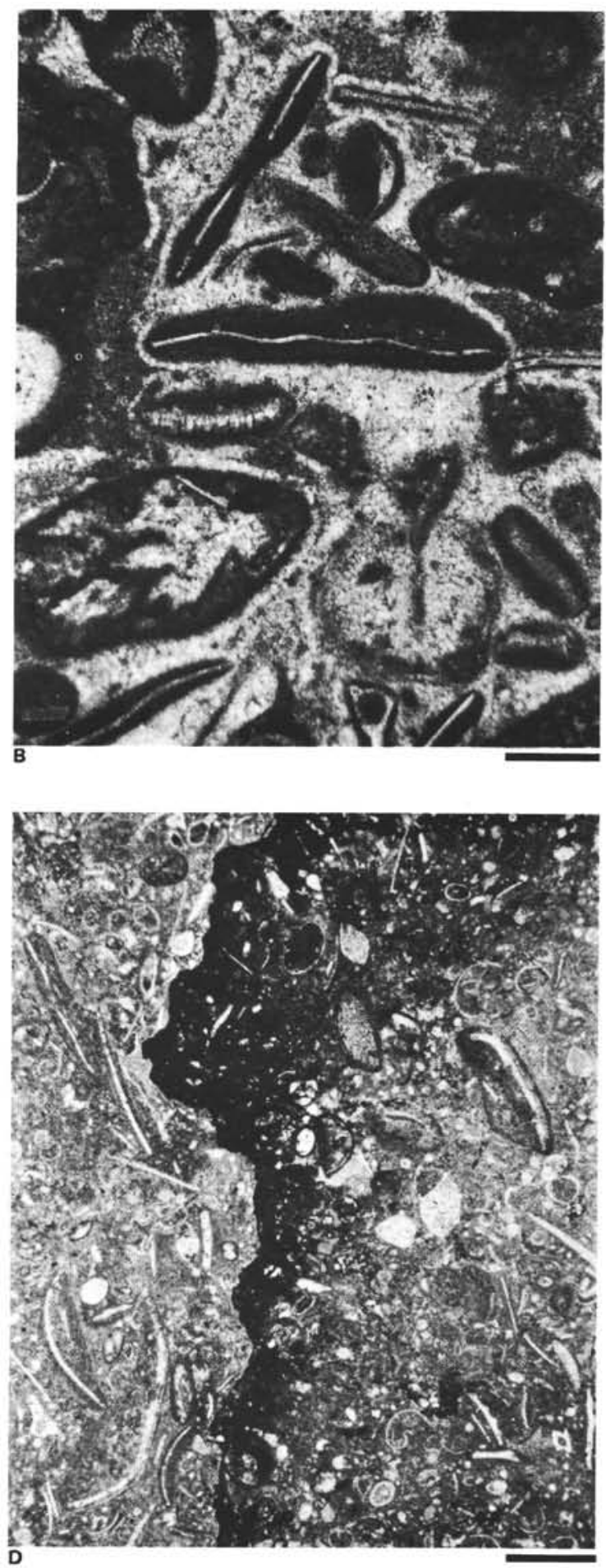

Figure 15. A. Skeletal-oncolith-peloid packstone with local patches of grainstone that are the result of bioturbation. The cyanobacterial nodules have skeletal debris as nuclei, and encrustations of algae and sessile foraminifers into which were incorporated additional skeletal debris during nodule growth. Matrix is silt-sized peloid packstone. Sample 544A-18-1, $3 \mathrm{~cm}$, thin section, crossed nicols, scale bar $1 \mathrm{~mm}$. B. Coated grains in a grainstone, with nuclei composed of undulatory filaments, echinoid fragments, and mollusk debris. Grains are cemented by a rim of bladed, sparry calcite which shows ghost "whisper aragonite" texture. The remaining interparticle voids are infilled by blocky, sparry calcite. Sample 544A-13-2, 39-44 cm, thin section, crossed nicols, scale bar $0.5 \mathrm{~mm}$. C. Shelter cavity in oncolith-skeletal packstone. The cyanobacterial nodules form the roof of the cavity, of which the walls are encrusted by cyanobacterial crust and sessile foraminifers. The cavity is filled by fine skeletal debris and calcisiltite; the remaining part of the void was filled by coarse, blocky calcite. Sample 544A-16-1, 83-89 cm, thin section, crossed nicols, scale bar $1 \mathrm{~mm}$. D. Well-developed nondepositional surface in skeletal-peloid packstone coated by $\mathrm{Fe} / \mathrm{Mn}$ layer which has a highly irregular surface. No visible change in limestone composition occurs across the surface, indicating that the interruption of deposition was not associted with a significant change of depositional environment. Note frequent pelagic pelecypods (filaments) and tests of foraminifers, ostracodes, and gastropods. Sample $544 \mathrm{~A}-13-1,22-27 \mathrm{~cm}$, thin section, crossed nicols, scale bar $0.5 \mathrm{~mm}$. 
Yucatan Shelf, which shows mixing of pelagic and shallow benthic biota and contains ooid-peloid intraclasts and algal oncoliths, closely resembles Site 544 lithology. The Progresso blanket contains up to $30 \%$ algal debris derived from the algae Halimeda, but debris of green algae is completely lacking at Site 544 . The explanation for this difference lies in the location of Site 544 on an offshore structural high. The presence of mixed shelf and pelagic fauna in the limestones of Unit III demonstrates that the high was adjacent to an open ocean, separated from the land by deeper water, as evidenced by lack of terrigenous detritus in the limestones. A carbonate bank developed on this outer basement high. The tectonic setting could have been similar to the present Flemish Cap east of the Grand Banks (offshore Canada), where the water depth is less than $200 \mathrm{~m}$ and the bank is separated from the mainland by a strait over $1000 \mathrm{~m}$ deep.

The lack of tidal deposits at the base of Unit III points to rapid transgression over the high. We attribute this to tectonic movements along faults. We suggest that, after rapid initial subsidence, the water depth over the bank during deposition of Unit III remained at about $100 \mathrm{~m}$, based on faunal assemblages and analogy with the modern Yucatan Shelf.

Lack of a well-developed nondepositional surface on top of the limestone of Unit III and the fresh appearance of the contact with the overlying Miocene oozes suggest that the surface is an erosional feature. The final erosion probably occurred during the Oligocene (Jansa, Enos, et al., 1979; von Rad and Wissmann, 1982).

Offshore carbonate banks with a similar depositional history to that of Site 544 were recognized in the Mediterranean region (Winterer and Bosellini, 1981). Probably the best analogy is with the Trento Platform in Italy, where the Bilobata Beds member of the Cape San Vigilio oolith is lithologically similar to the limestones of Site 544 . Both sequences are composed mainly of packstone with pelagic oolites and oncoliths, and both contain mixed shelf and pelagic fauna. Pelagic pelecypods (filaments) are a common constituent of Site 544 limestones (Fig. 13), as similarly found in the Posidonia Alpina Beds, which are of Bajocian to early Bathonian age and which overlie the Toarcian-Aalenian Bilobata Beds (Assereto et al., 1975). This suggests a younger age for the limestones of Unit III, which are perhaps coeval with the Posidonia Alpina Beds or with the Ammonitico Rosso Veronese of the Trento Platform.

\section{Age}

Study of fossils from the limestones of Unit III has not yielded conclusive age information. The few nannofossils found in 544A-13-2, $27 \mathrm{~cm}$, for example Watznaueria barnesae and Coccolithus deflandrei, were overgrown and do not provide a very accurate date, but their abundance is characteristic of the Kimmeridgian-Tithonian (M. K. Cooper, pers. comm, 1983). A single specimen of the nannofossil Stephanolithion bigotii, found in Sample 544A-14-1, $120 \mathrm{~cm}$, has an early Callovian to middle Kimmeridgian range (Wiegand, this volume).
Planktonic foraminifers, particularly Protoglobigerina sp., which, according to Azéma and Jaffrezo (this volume) is a common constituent of the limestones, has been found to be very rare by the authors. The pelagic pelecypods (filaments) are common and, together with protoglobigerinids, are characteristic of the Middle to lower Upper Jurassic rocks of the Mediterranean region, as discussed earlier. The scarceness of saccocomids and the total lack of calpionellids, which both occur in the adjacent Site 547, indicate that the limestones are not younger than Oxfordian. Because pelagic pelecypods are also a common constituents of the Middle Jurassic at Sites 545 and 547, and because a major transgression occurred on the Moroccan margin during the Bathonian, we suggest that the basal carbonates at Site 544 are probably Bathonian-Callovian in age. If we assume such a time span for Unit III, then the very low depositional rate of $2 \mathrm{~m} / \mathrm{m}$.y. does not appear to be consistent with the character of the deposited sediment. Unless the incipient hardgrounds represent larger time condensation than assumed by the authors, the limestones of Unit III were deposited in a shorter time span than we have indicated.

\section{DISCUSSION}

The sites drilled during Leg 79 have revealed the complex tectonic structure of the outer continental margin, which dates back to the early rifting of Pangea, and have contributed to our understanding of the evolution of deep carbonate platforms constructed at the edges of the continents. They have also provided new data about early paleoceanography and the Jurassic stratigraphy of the evolving central North Atlantic Basin. Evolution of the margin in the Mazagan Plateau area is summarized in Figure 16, which shows reconstructed paleogeography of the region during the late Triassic to Early Cretaceous. These aspects of the Leg 79 contributed to North Atlantic geology are discussed in more detail below.

\section{Tectonics}

During the Early Jurassic, the outer continental margin off Morocco was tectonically differentiated into structural highs and lows (Fig. 16A,B). The difference in grain size of the sediments deposited during the Triassic (dominated by mudstones) and Early Jurassic (gravityredeposited limestone breccia beds) may indicate that a major period of faulting at the Triassic/Jurassic boundary of offshore Morocco rejuvenated or magnified the existing relief. Based on seismic reflection profiles, a similar period of Early Jurassic tectonism has been recognized on the conjugate eastern North American margin (Schlee and Jansa, 1981; Jansa and Wade, 1975). Seaward of the Mazagan Plateau, the structural sub-basins (grabens) had already subsided below global sea level during the earliest Jurassic (Fig. 16A). During the global sea level rise in the Sinemurian these seaward sub-basins were flooded by the rising sea. Some of the surrounding basement highs, such as Site 544, remained emergent up to the Middle Jurassic.

The occurrence of a basement high at the outer edge of the continent was suggested by Schuepach and Vail 

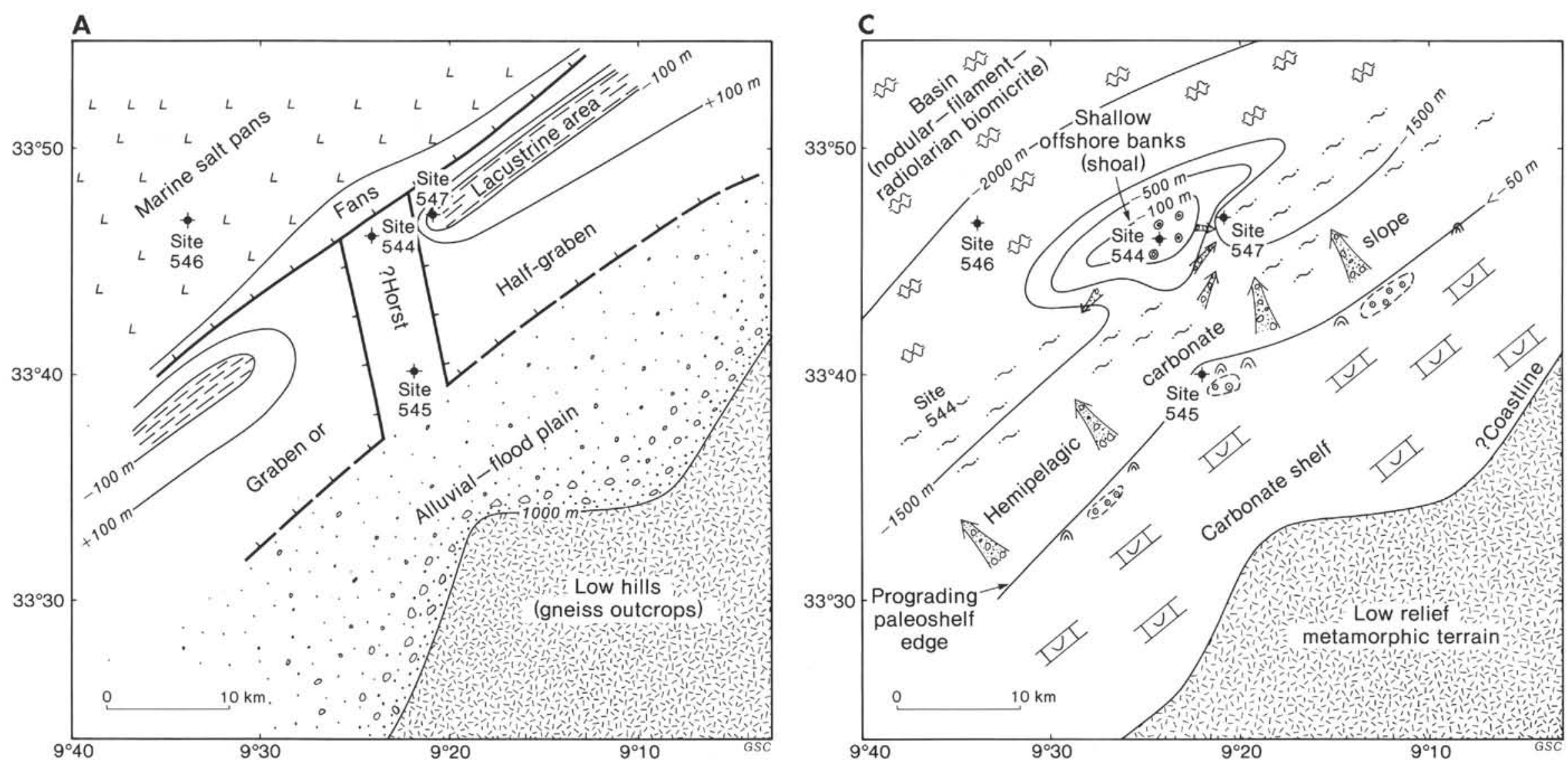


\section{B}

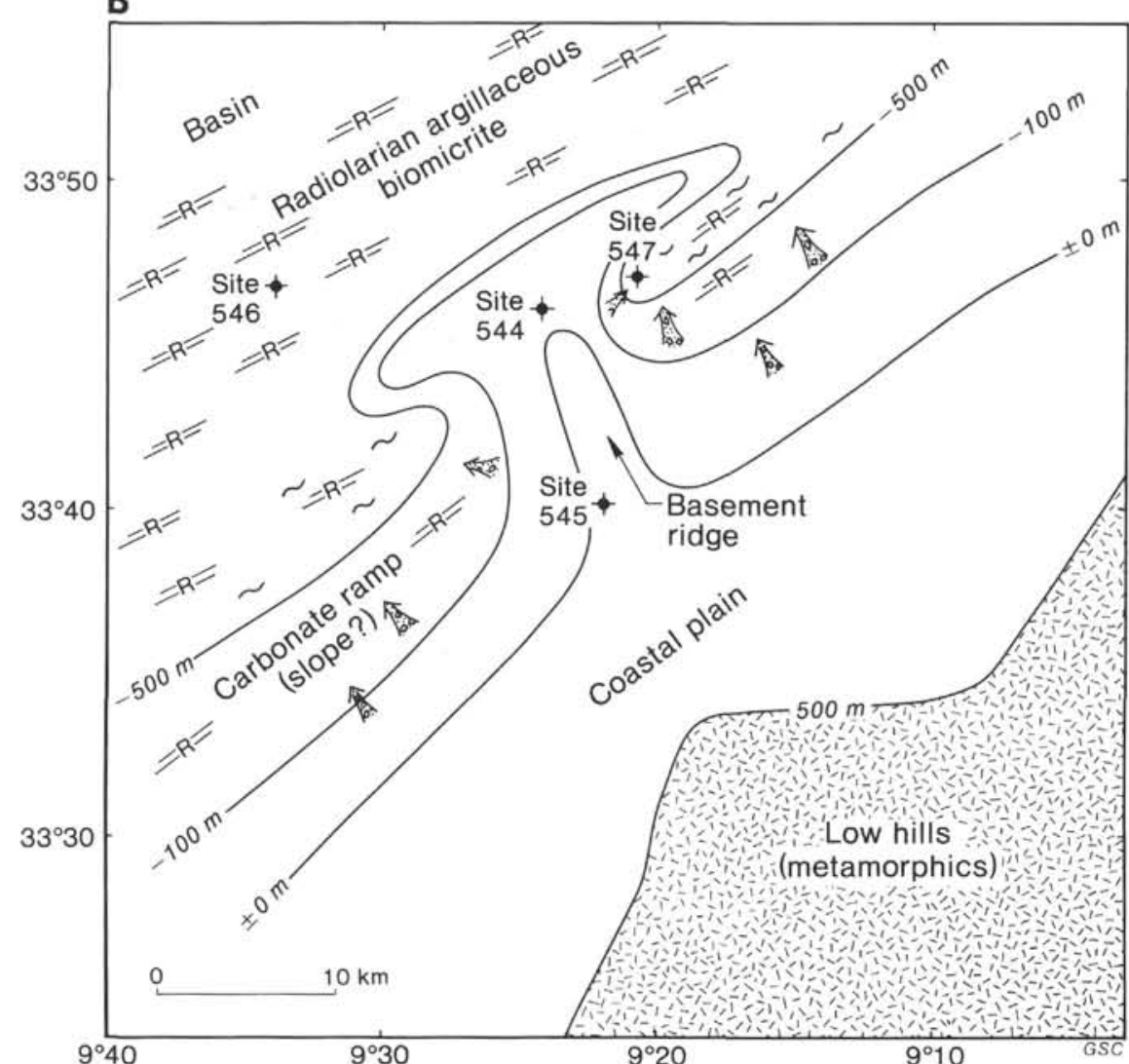

Gravity-displaced deposits

6. (limestone debris flow, turbidites)

Late Jurassic carbonates exposed at Mazagan Escarpment

$\sim$ Argillaceous biomicrite

\begin{abstract}
工 $\begin{aligned} & \text { Pelagic carbonate } \\ & \text { (biomicrite) }\end{aligned}$
\end{abstract}
$\square$ Skeletal limestone
D

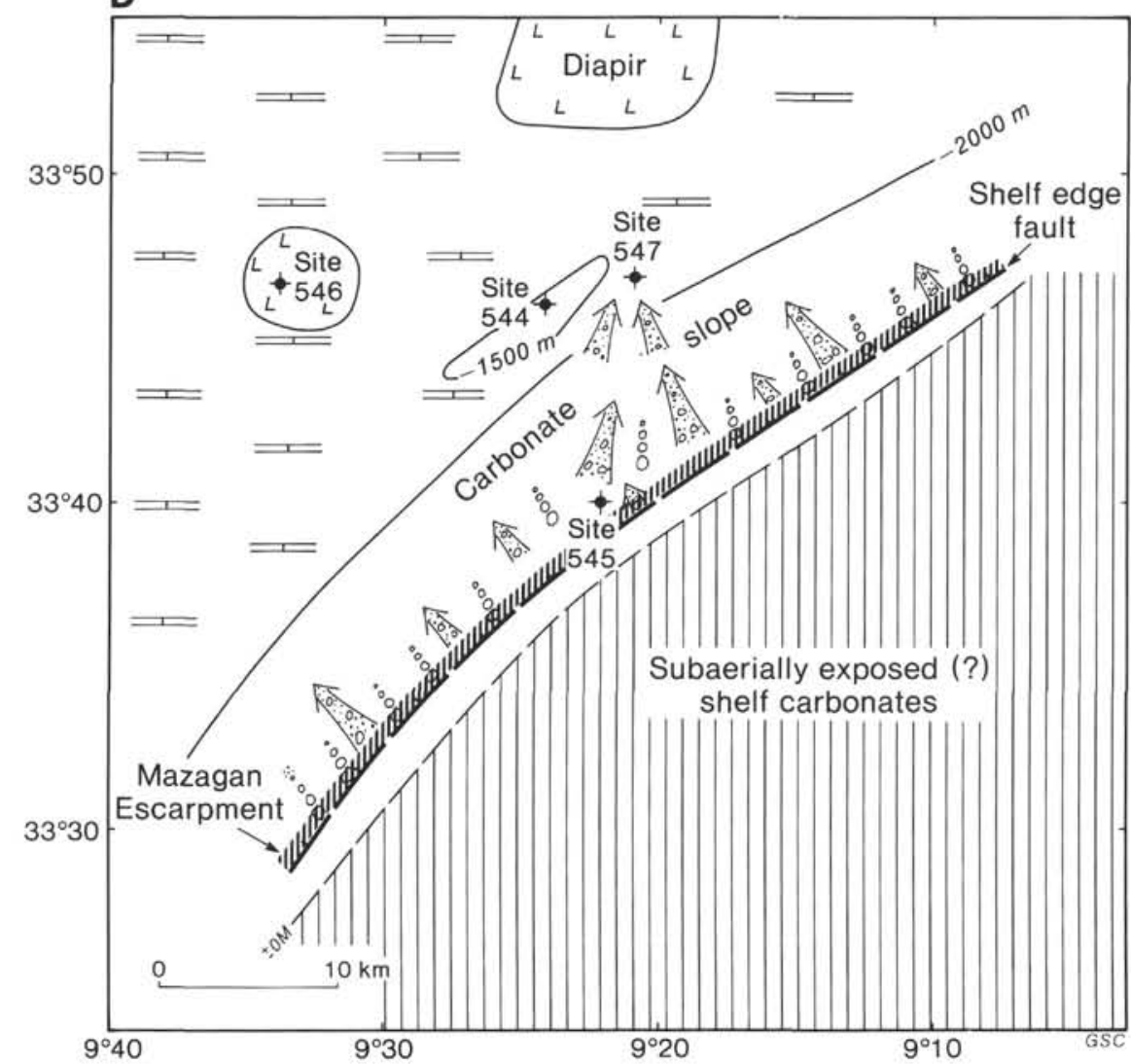

A Bioherms

.000 Carbonate talus deposits

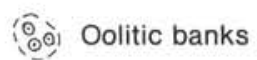

(L) Salt diapir

〜. Quartz-silty biomicrite

Nodular-filament
biomicrite (basin)

Area of erosion, dolomitization

Figure 16. Reconstructed paleogeographic map of the Mazagan Plateau front: A. Late Triassic-earliest Jurassic. The depressions in the graben or half-graben were locations of lake deposition and had already subsided below sea level, as in the present Dead Sea rift zone. B. Pliensbachian. The presence of limestone debris flow beds at Site 547 indicates that the margin had the morphological shape of a carbonate ramp. The radiolarian-spiculitic biomicrite clasts, which were derived from the ramp slope, indicate that a deeper pelagic environment already existed above Site 547 during the early Jurassic. C. Oxfordian. The basement high at Site 544 which was transgressed during the Middle Jurassic developed into a shallow offshore shoal area covered by an oncolithskeletal limestone. Hemipelagic carbonates continued to be transported toward the base of the slope in debris flows from the Mazagan Plateau slopes. Oolitic shoals and isolated bioherms were constructed at the prograding paleoshelf edge. D. Hauterivian-Barremian. During the Early Cretaceous the carbonate-shelf edge was probably subaerially exposed, eroded, and then faulted. Variable movements occurred along individual tectonic blocks constructing the outer continental margin. The paleshelf edge was transgressed during the Albian, and pelagic terrigenous deposits cov- 
(1980), who indicated that outer highs are frequent along divergent continental margins, and that they delineate the boundary between continental and oceanic crust. As demonstrated by Leg 79 , the outer basement highs are present at the outer continental margin, but they are located along the flank of the central rift, if we accept the theory that the seaward edge of the diapiric salt zone marks the boundary between continental and oceanic crust. The basement high of Site 544 is located at least $50 \mathrm{~km}$ landward of the oceanic/continental crust boundary.

Extensive faulting of the outer Mazagan Plateau has been observed during recent CYANA dives (Auzende et al., this volume). The faults that parallel the slope have displacements of up to $1000 \mathrm{~m}$. The occurrence of faults near the edges of submerged carbonate platforms is common (Freeman-Lynde et al., 1981), but this phenomenon has not been satisfactorily explained in the literature. Shelf-edge faults are common along carbonate platforms in marginal basins; for example, the Jurassic shelf-edge fault is exposed in the Middle Atlas of Morocco. We suggest that shelf parallel faulting is magnified by synsedimentary processes and enhanced by differential compaction between shelf and slope carbonates. During studies of cores from Leg 79, we observed that shelf carbonates were lithified earlier than coeval pelagic carbonates of the slope. The explanation lies in the different mineralogy of carbonates accumulated on the shelf and slope. Unstable aragonite and high- $\mathrm{Mg}$ calcite are frequent constitutents of the skeletal carbonates on shelves, but the hemipelagic and pelagic carbonates are composed mainly of stable, low-Mg calcite, so that slope deposits are lithified later than shelf carbonates. Therefore, we suggest that differential compaction between shelf and slope carbonates enhanced the relief of the shelf-edge faults because of the development of synsedimentary faults. Furthermore, with favorable conditions, such as the presence of contour-currents, a carbonate escarpment might develop at the seaward edge of the carbonate platform as has been observed on the Mazagan Plateau, the Blake Plateau, and the Bahamas. How much of the escarpment relief is the result of faulting and how much is caused by contour-current erosion is unknown.

\section{Carbonate Platform Evolution}

One of the most interesting results of Leg 79 is the recovery of basinal sediments that mark the onset of marine deposition in the central North Atlantic Basin. These are not shallow-water deposits, as might be expected, but rather "deep" water deposits. These basinal sediments are mainly dark gray, calcareous shales and marls which almost completely lack preserved skeletal remains. The lack of fossils can be explained either by the high toxicity of bottom waters, which might have dissolved some of the evaporites incorporated into the underlying deposits, or by the low biological productivity of surface water in the incipient central North Atlantic or by the presence of carbonate-undersaturated bottom waters. In the last case, the undersaturation would cause an elevated CCD and thus dissolution of carbon- ates at the sea bottom. We suggest that the scarcity was the result of the early biological evolution of the calcareous plankton (plankton was rare) in combination with the low productivity of surface waters, because during this time only the old surface waters from Tethys were transported into the central North Atlantic.

At the toe of the carbonate platform, gravity deposits were accumulating throughout the Jurassic. Here it is important to emphasize the special tectonic setting of Site 547 , which was surrounded on three sides by elevated terrains (Fig. 16B). Thus, the debris flows were funneled toward Site 547. Because of this special tectonic setting, the lithological development observed at Site 547 may not be typical for other open carbonate platforms which rimmed the North Atlantic margins (Jansa, 1981). The individual debris flows at the toe of the slope are several tens of centimeters to several meters thick and originally had high shelter porosity that was completely occluded by internal sediment deposited in the cavities, followed by infilling of the remaining voids by late diagenetic sparry calcite cement. Such as wedge of carbonate debris is not unique for the carbonate platform fronts off Morocco. A similar wedge of gravitytransported limestone breccia beds developed during the Early and Middle Jurassic in the central Appennines, where it separates the steep slope of the Latium-Abruzzi carbonate platform from the Umbro-Sabino Basin (Colacicchi and Passeri, 1981; Colacicchi, 1982).

The evolutionary history of the outer carbonate margin of the Mazagan Plateau can be reasonably well interpreted from the composition of clasts accumulated in debris flows at Site 547. The dominance of radiolarianspiculitic biomicrite clasts in the Lower Jurassic redeposited beds indicates that the margin and the physiographic shape of a ramp (Ahr, 1973; Fig. 16B). The hemipelagic slope deposits were displaced from time to time to the toe of the slope as debris by gravity transport.

During the Middle Juassic regression, limestone debris became coarser with an open, clast-supported fabric of breccia beds, indicating more proximal derivation of clasts. The indurated limestone clasts were derived from a shallow carbonate shelf. During the same period, terrigenous quartz and clasts of sandstones were transported to the basin floor from surrounding basement highs.

During the Bathonian or Oxfordian transgression, the outer basement high on which Site 544 was located was flooded by a shallow sea. The absence of shallow-water carbonates at the base of the carbonate platform, which is constructed over this offshore basement high, indicates the high subsided rapidly below sea level. From this we conclude that initial subsidence was tectonic and probably the result of downfaulting.

The time of flooding of the structural high is constrained by the disappearance of red-colored sandstone clasts from debris flows at Site 547 and by the appearance of the pelagic oolites and oncoliths characteristic of Site 544 deposition at Site 547. The Middle Jurassic transgression also left a lithological overprint on the upper slope of the Mazagan Plateau, in the progressive 
disappearance of terrigeneous clastics, which were mixed with shallow-platform carbonates, including oolites and pelagic biota, at the base of Site 545 .

Significant changes in limestone composition occurred during the Late Jurassic. Debris flows became less frequent, clasts were finer-grained, and pseudonodular and nodular limestone deposits were intercalated with pelagic carbonates. The limestone from site 547 and stratigraphic development of Site 545 indicate that during the Late Jurassic coral-sponge bioherms, as well as high-energy oolitic shoals, were present along the outer shelf edge, similar to those observed on the conjugate Scotian Shelf margin (Jansa, 1981; Jansa et al., 1982). A carbonate platform developed during the early Late Jurassic at the Mazagan Plateau and it continued to build outward and upward (Fig. 16C).

The late history of the Mazagan carbonate platform is not so clear. From the composition of clasts incorporated in the Miocene limestones debris flows, we know that carbonate deposition continued into the Early Cretaceous, with a deep shelf environment exisitng near the shelf edge of the Mazagan Plateau during the late Tithonian. A thick sequence of shelf-lagoon debris, having a porosity of up to $30 \%$, accumulated at the top of the carbonate platform at Site 545 during the Late Jurassic. If these deposits represent in situ periplatform debris of the shelf lagoon, then they document extensive downfaulting of the outer carbonate margin, which would have to postdate the deposition of the uppermost carbonates at Site 545 .

\section{Drowning of the Carbonate Platform}

Carbonate deposition on the Mazagan Plateau terminated after the Berriasian and before the early late Aptian (Fig. 16D), since the carbonate platform is covered by chalks of early late Aptian age. The presence of chalkified limestones and the intensive dolomitization and leaching observed at the top of the platform limestones in Site 545 (Fig. 6C) indicates that the platform surface was probably subaerially exposed with leaching and dolomitization occurring in a vadose and mixing zone. The absence of nondepositional surface at the top of the carbonate platform and the fresh appearance of the limestones at the unconformity point to a period of erosion which preceded final burial of the platform. The erosion of the platform has been recognized by Schlager (1980), who dated drowning of the platform to the Valanginian by changes in the composition of limestone turbidite beds in the deep Moroccan basin. After subsidence resumed or a new period of transgression began, the Mazagan Plateau was covered by hemipelagic to pelagic carbonate chalks and marls during the Aptian. The renewed submergence did not lead to continued shallow-water carbonate deposition and growth of the carbonate platform; instead, the deposits were hemipelagic. Perhaps it was the rapidity of the transgression which did not allow colonization of the sea bottom by shallow carbonate-platform biota.

From a paleoceanographic point of view, it is important to note that a similar unconformity separates Albian hemipelagic deposits from underlying Lower Creta- ceous pelagic carbonates at the toe of the carbonate platform off the Mazagan Plateau (Site 547). This hiatus can be explained either by strong bottom currents which eroded the margin during the Early Cretaceous, or, less probably, by the fact that most carbonate at the slope toe was transported into the basin from the shallow carbonate platform. The lack of nondepositional surfaces at the top of the carbonate platform at Sites 545 and 547 indicates that at least a brief period of erosion preceded deposition of the Aptian-Albian chalks and claystones that envelop the Jurassic carbonate platform all around the western Moroccan margin (Jansa, Gardner, et al., 1979; Lancelot, Scibold, et al., 1979; Schlager, 1980).

\section{Site 547 and Jurassic Deep Sea Lithostratigraphy}

Site 547 contributes greatly to our knowledge of Jurassic deep sea stratigraphy for the central North Atlantic. Before Leg 79, the oldest sediments known were Callovian, dark gray, organic-matter-rich shales and marls from the Blake-Bahama Basin (Sheridan, Gradstein, et al., 1983; Ogg et al., 1983).

Drilling off Morocco shows that the Callovian, lowoxygenated bottom conditions were probably restricted to parts of the Blake-Bahama Basin. This conclusion is supported by the return to high-oxygenated conditions at the base of the (?)Callovian sequence at Site 534 (Ogg et al., 1983).

Reddish brown, nodular limestones intercalated with marls were typical lithology of the Upper Jurassic Cat Gap Formation in the western central North Atlantic as defined by Jansa, Enos, et al. (1979). The lithologic characteristic of Subunit VIA2 at Site 547 and its fauna demonstrates that this unit is not only lithologically similar, but also synchronous with the Cat Gap Formation. The Cat Gap Formation in the western North Atlantic is overlain by light gray, pelagic limestones intercalated with greenish gray marls of the Blake-Bahama Formation, a lithologic development similar to Subunit VIA1. Synchroneity of the latter units is also confirmed by the fauna. Thus we conclude that the Late Jurassic stratigraphic framework, as recognized in the western and southeastern central North Atlantic, is also applicable in the northeastern central North Atlantic, as previously suggested by Bernoulli (1972), Jansa (1978), and Jansa, Gardner, et al. (1979). Applicability of the Jurassic stratigraphic framework from the North American basin to the eastern central North Atlantic documents the similarity of basin development along the North American and African continental margins.

The Lower Jurassic at Site 547 could have been strongly influenced by a specific tectonic setting, as already discussed, and thus any stratigraphic conclusions based on this site will be premature. However, the dominance of dark gray marls and shales observed in the Lower Jurassic at Site 547 is also a characteristic feature of the Lower Jurassic in southwestern Germany (Urlichs, 1977), and southern France (Digne Basin; deGraciansky et al., 1980). The similarity between Lower Jurassic deposits of western Europe and those encountered offshore Morocco may support Jansa and Wade's (1975) hypothesis 
that the Early Jurassic central North Atlantic was an epicontinental basin. This basin, according to faunal evidence (Ager, 1974), was connected with the western European epicontinental seas via a Portugal or Grand Banks passage, since the "Gibraltar-Rif" seaway was closed or highly restricted at this time. The latter seaway was opened to the Mediterranean Tethys during the late Early Jurassic and was of increasing paleoceanographic importance through the Middle and Late Jurassic (Hallam, 1977, 1983; Jansa, in press).

\section{ACKNOWLEDGMENTS}

We are grateful to A. C. Grant, W. E. Dean, and R. M. Leckie for critically reviewing the manuscript and for the helpful suggestions in improving the text. L. Jansa acknowledges the generous support of the Geological Survey of Canada and the Atlantic Geoscience Centre in this study. Finally we are indebted to C. Mitchell for typing the manuscript and to G. Cook and P. Lake for drafting assistance.

\section{REFERENCES}

Adams, A. E., 1979. Sedimentary environment and paleogeography of the western High Atlas, Morocco, during the Middle and Late Jurassic. Paleogeogr., Paleoclimatol., Paleoecol., 28:185-196.

Ager, D. V., 1974. The western High Atlas of Morocco and their significance in the history of the North Atlantic. Proc. Geol. Assoc. $85: 23-41$.

Ahr, W. M., 1973. The carbonate ramp: an alternative to the shelf model. Trans. Gulf Coast Assoc. Geol. Soc., 23:221-225.

Ambroggi, R., 1963. Etude Géologique du Versant Méridional du Haut Atlas Occidental et de la Plaine du Souss. Not. Mem. Serv. Geol. Maroc, 157.

Arthur, M. A., and Schlanger, S. O., 1979. Cretaceous "oceanic anoxic event" as casual factors in development of reef-reservoired giant oil fields. Am. Assoc. Pet. Geol. Bull., 63:870-885.

Assereto, R., Clari, P. A., Gaetani, M., Massari, F., Sorbini, L., and Sturani, C., 1975. Field Guide, Excursion A14, IX Int. Sedim. Congr., Nice.

Bernoulli, D., 1972. North Atlantic and Mediterranean Mesozoic facies: A comparison. In Hollister, C. D., Ewing, J. I., et al., Init. Repts. DSDP, 11: Washington (U.S. Govt. Printing Office), 801-872.

Bhat, H., McMillan, N. J., Aubert, J., Porthault, B., and Surin, B., 1975. North American and African drift: The record in Mesozoic coastal plain rocks, Nova Scotia and Morocco. In Yorath, C. J., Parker, E. R., and Glass, D. J. (Eds.); Canada's Continental Margins and Offshore Petroleum Exploration. Can. Soc. Pet. Ceol. Mem., 4:375-389.

Bourbon, M., 1978. Mesozoic evolution of western North Atlantic and north Tethyan margins: A comparison. In Benson, W. E., Sheridan, R. E., et al., Init. Repts. DSDP, 4: Washington (U.S. Govt. Printing Office), 949-970.

Colacicchi, R., 1982. Platform-slope basin system in the CretaceousTertiary of Central Appennines. Abstr. XI Int. Sedimentol. Cong., Hamilton, Ont., p. 45.

Colacicchi, R., and Passeri, L., 1981. Mesozoic pelagites and their relations to carbonate platform margin in Umbria-Marche Appennines. Excursion Guidebook, 2nd Eur. Reg. Meeting Int. Assoc. Sedimentol., Bologna, pp. 69-76.

Cussey, R., Grosdidier, E., Sulpice, L., and Umbach, P., 1982. Carbonate shelf reservoirs: The Middle Jurassic of the Paris Basin, France. In Reeckmann, A., and Friedman, G. M. (Eds.), Exploration for Carbonate Petroleum Reservoirs: New York (J. Wiley \& Sons), pp. 119-130.

Dean, W. E., Gardner, J. V., Jansa, L. F., Čepek, P., and Seibold, E., 1979. Cyclic sedimentation along the continental margin of Northwest Africa. In Lancelot, Y., Seibold, E., et al., Init. Repts. DSDP, 41: Washington (U.S. Govt. Printing Office), 965-990.

deGraciansky, P. C., Lemoine, M., Arnaud-Vanneau, A., Arnaud, H., Beadoin, B., Bourbon, M., Chenet, P. Y., Elmi, S., and Ferry S., 1980. European continental margin of the Mesozoic Tethys in the western Alps. Guidebook for Excursion 27C, 26th Int. Geol. Cong., Paris, pp. 119-148.
Dott, R. H., Jr., 1963. Dynamics of subaqueous gravity depositional processes. Am. Assoc. Pet. Geol. Bull., 47:104-128.

Faure-Muret, A., and Schoubert, G., 1971. Le Maroc. Domaine rifaine et atlasique. Tectonique de l'A frique: Paris (UNESCO), pp. $17-46$.

Freeman-Lynde, R. P., Cita, M. B., Jaoul, F., Miller, E. L., and Ryan, W. B. F., 1981. Marine geology of the Bahama Escarpment. Mar. Geol. 44:119-156.

Grunau, H. R., Lehner, P., Cleintaur, M. R., Allenbach, P., and Bakker, G., 1975. New radiometric ages and seismic data from Fuerteventura (Canary Islands), Maio (Cape Verde Islands) and Sao Tome (Gulf of Guinea). In Borradaille, G. J. et al. (Eds.), Progress in Geodynamics: Amsterdam (R. Neth. Acad. Arts Sci.) pp. 90-118.

Hallam, A., 1977. Biogeographic evidence bearing on the creation of Atlantic seaways in the Jurassic. In West, R. M. (Ed.), Paleontology and Plate Tectonics, Milwaukee Public Museum Spec. Publ. Biol. Geol., 2:23-39.

1983. Early and Mid-Jurassic molluscan biogeography and the establishment of the central Atlantic seaway. Paleogeogr., $\mathrm{Pa}$ leoclimatol., Paleoecol., 43:181-193.

Hinz, K., Dostmann, H., and Fritsch, J., 1982. The continental margin of Morocco: Seismic sequences, structural elements and geological development. In von Rad, U., Hinz, K., Sarnthein, M., and Seibold, E. (Eds.), Geology of the Northwest African Continental Margin: Berlin (Springer-Verlag), pp. 34-60.

Hollister, C. D., Ewing, J. I., et al., 1972. Init. Repts. DSDP, 11: Washington (U.S. Govt. Printing Office).

Jansa, L. F., 1978. Le Crétaceé au large de la marge ibérique. Cah. Micropaleontol. 4:47-56.

1981. Mesozoic carbonate platforms and banks of the eastern North American margin. Mar. Geol. 44:97-117.

in press. Paleooceanography and evolution of the North Atlantic Ocean Basin during the Jurassic. In Tucholke, B. E., Vogt, P. (Eds.) The Geology of North America (Vol. 1): Boulder (Geol. Soc. Am.).

Jansa, L. F., Enos, P., Tucholke, B. E., Gradstein, F. M., and Sheridan, R. E., 1979. Mesozoic-Cenozoic sedimentary formations of the North American Basin; western North Atlantic. In Talwani, M., Hay, W., Ryan, W. B. F. (Eds.), Deep Drilling Results in the Atlantic Ocean: Continental Margins and Paleoenvironment. Am. Geophys. Un., Maurice Ewing Ser., 3:1-57.

Jansa, L. F., Gardner, J. V., and Dean, W. E., 1979. Mesozoic sequences of the central North Atlantic. In Lancelot, Y., Seibold, E., et al., Init. Repts. DSDP, 41: Washington (U.S. Govt. Printing Office), 991-1031.

Jansa, L. F., Termier, G., and Termier, H., 1982. Les biohermes à algues, spongiaires et coraux du séries carbonatées de la flexure bordière du "paleoshelf" au large du Canda oriental. Rev. Micropaleontol., 25:181-219.

Jansa, L. F., and Wade, J. A., 1975. Geology of the continental margin off Nova Scotia and Newfoundland, In van der Linden, W. J. M., and Wade, J. A. (Eds.), Offshore Geology of Eastern Canada, 2. Regional Geology, Geol. Surv. Canada, Paper 74-30:51-106.

Jansa, L. F., and Wiedmann, J., 1982. Mesozoic-Cenozoic development of the eastern North American and northwest African continental margins: A comparison. In von Rad, U., Hinz, K., Sarnthein, M., and Seibold, E. (Eds.), Geology of the Northwest African Continental Margin: Berlin (Springer-Verlag), pp. 215-269.

Jenkyns, H. C., 1972. Pelagic "oolites" from the Tethyan Jurassic. $J$. Geol., 80:21-33.

Lancelot, Y., Seibold, E., et al., 1979. Init. Repts. DSDP, 41: Washington (U.S. Govt. Printing Office).

Lancelot, Y., Winterer, E. L., et al., 1980, Init. Repts, DSDP, 50: Washington (U.S. Govt. Printing Office).

Lehner, P., and De Ruiter, P. A. C., 1977. Structural history of Atlantic margin off Africa. Am. Assoc. Pet. Geol. Bull., 61:961-981.

Logan, B. W., Harding, J. L., Ahr, W. M., Williams, J. D., and Snead, R. G., 1969. Carbonate Sediments and Reefs, Yucatan Shelf, Mexico, Am. Assoc. Pet. Geol. Mem., 11:3-128.

Ogg, J. G., Robertson, A. H. F., and Jansa, L. F., 1983. Jurassic sedimentation history of Site 534 (western North Atlantic) and of the Atlantic-Tethys Seaway. In Sheridan, R. S., Gradstein, F. M., et al., Init. Repts. DSDP, 76: Washington (U.S. Govt. Printing Office), 829-884. 
Quiuyuan, L., and Wenxue G., in press. The characteristics of Cenozoic sedimentary basins in the North China Platform. In Jansa, L. F., Burollet, P. F., and Grant, A. C. (Eds.), Sedimentary Basins: Principles and Applications. Sediment. Geol. Spec Issue: Amsterdam (Elsevier).

Renz, O., Imlay, R., Lancelot, Y., and Ryan, W. B. F., 1975. Ammonite-rich Oxfordian limestones from the base of the continental slope off Northwest Africa. Eclogae Geo. Helv., 61:431-448.

Schlager, W., 1980. Mesozoic calciciturbidites in Deep Sea Drilling Project, Hole 416A; Recognition of a drowned carbonate platform. In Lancelot, Y., Winterer, E. L., et al., Init. Repts. DSDP, 50: Washington (U.S. Govt. Printing Office), 733-749.

Schlee, J. S., and Jansa, L. F., 1981. The paleoenvironment and development of the eastern North American continental margin. Geology of Continental Margins, Symp. (Proc. 26th Int. Geol. Cong., Paris, July 7-17, 1980). Oceanol. Acta, Suppl. Vol. 4:71-80.

Schuebpack, M. A., and Vail, P. R., 1980. Evolution of outer highs on divergent continental margins. Continental Tectonics: Studies in Geophysics: Washington (National Research Council, National Academy of Science), pp. 50-61.

Sheridan, R. E., Gradstein, F. M., et al., 1983. Init. Repts. DSDP, 76: Washington (U.S. Govt. Printing Office).

Taieb, M., 1976. Evolution of Plio/Pleistocene sedimentary basin of the central Afar (Awash Valley, Ethiopia). Afar between Continental and Oceanic Rifting: Stuttgart (Inter-Union Commission on Geodynamics, Science Report), 16:80-87.
Thierstein, H. R., 1976. Mesozoic calcareous nannoplankton biostratigraphy of marine sediments. Mar. Micropaleontol, 1:325-362.

Urlichs, M., 1977. The Lower Jurassic in southwestern Germany. Stuttgarter Beitr. Naturk., Ser. B, 24:1-41.

von Rad, U., and Wissmann, G., 1982. Cretaceous-Cenozoic history of the West Saharan continental margin (NW Africa): Development, destruction and gravitational sedimentation. In von Rad, U., Hinz, K., Sarnthein, M., and Seibold, E. (Eds.), Geology of the Northwest African Continental Margin: Berlin, (Springer-Verlag), pp. 106-131.

Wiedmann, J., Butt, A., and Einsele, G., 1982. Cretaceous stratigraphy, environment and subsidence history at the Moroccan continental margin. In von Rad, U., Hinz, K., Sarnthein, M., and Seibold, E. (Eds.), Geology of the Northwest African Continental Margin: Berlin (Springer-Verlag), pp. 366-395.

Wilson, J. L., 1975. Carbonate facies in Geologic History: New York (Springer-Verlag).

Winterer, E. L., and Bosellini, A., 1981. Subsidence and sedimentation on Jurassic passive continental margin, southern Alps. Italy. Am. Assoc. Pet. Geol. Bull., 65:394-421.

Wissmann, G., and von Rad, U., 1979. Seismic structure, continental basement, and Mesozoic sediments from the Mazagan Plateau off Morocco. "Meteor" Forsch.-Erg., Reihe C, 31:1-20.

Date of Initial Receipt: February 14, 1984 Date of Acceptance: February 16, 1984 